\title{
Review Article \\ Surface Engineered Polymeric Biomaterials with Improved Biocontact Properties
}

\author{
Todorka G. Vladkova \\ Laboratory for Advanced Materials, Department of Polymer Engineering, University of Chemical Technology and Metallurgy, \\ $8 \mathrm{Kl}$. Ohridski Boulevard., 1756 Sofia, Bulgaria \\ Correspondence should be addressed to Todorka G. Vladkova, tgv@uctm.edu
}

Received 4 August 2009; Revised 24 November 2009; Accepted 31 March 2010

Academic Editor: Shanfeng Wang

Copyright ( $\odot 2010$ Todorka G. Vladkova. This is an open access article distributed under the Creative Commons Attribution License, which permits unrestricted use, distribution, and reproduction in any medium, provided the original work is properly cited.

We present many examples of surface engineered polymeric biomaterials with nanosize modified layers, controlled protein adsorption, and cellular interactions potentially applicable for tissue and/or blood contacting devices, scaffolds for cell culture and tissue engineering, biosensors, biological microchips as well as approaches to their preparation.

\section{Introduction}

On many parameters, polymeric materials satisfy the requirements of biomedical applications. However, the last ones are limited in most cases by the nonsufficient biocontact properties of the polymer. Surface engineering creating nanosize layers with controlled chemical composition, topography and roughness, and hydrophilic/hydrophobic balance emerged as a simple, useful, and versatile approach to solve the problem.

From the mid-1900s to the end of the last century, biomaterials were petroleum-derived synthetic polymers designed to be inert in vivo, that is, to perform their function without interacting with the organism [1]. These biomaterials are characterized with exclusively low protein adsorption and weak interactions with blood, living tissues, and cells. Over the past decades, many new synthetic and biologically derived polymers have been studied and applied, altering this paradigm [2, 3]. Now material scientists have shifted toward the design of bioactive materials that integrate with biological molecules or cells and regenerate tissue [4-6]. Biomaterials for regenerative medicine and tissue engineering gain special interests. Tissue engineering is based on cell seeding on a substrate followed by culturing in bioreactor or directly in the human body. The substrate is often a polymeric biomaterial that should stimulate not only the cell attachment and differentiation but also the extra cellular matrix formation and tissue regeneration. Advanced biospecific and biomimetic materials consisting of bioinert environment enriched of ligands for adhesive receptors, usually short amino acid sequences, like Arg-Gly-Asp or carbohydrates and/or functional parts of hormones, enzymes or growth factors, are currently under intense investigation $[7,8]$.

Limited knowledge about the interface phenomena on the border of the living and nonliving matter, such as protein adsorption and bioadhesion, are the theoretical base for the development of bioinert or bioactive surface engineered biomaterials. The mechanisms of protein adsorption and bioadhesion are a key question in many studies but despite the enormous efforts, they remain not fully understood.

The biological cascade of all nondesirable reactions against biomaterials begins with deposition of proteins. Protein adsorption is the primary event in the biofouling. Secreted by cells, adhesive proteins mediate their interaction with the biomaterial surface. Therefore, many investigations are devoted to studying the adsorption mechanism of single, well-defined proteins or of concurrent adsorption from double and multicomponent systems on different surfaces [9-12]. Because of their versatile nature many proteins can 
be adsorbed via many mechanisms when they are in front of complementary surfaces [13], which makes it difficult to control protein adsorption.

Knowing the mechanism of cell/surface interaction is very important for the design of biomaterial surfaces with improved biocontact properties. General theory of bioadhesion does not exist up to now despite the fundamental understanding of its molecular mechanisms can lead to the creation of material surfaces that can reduce or support the cell/biomaterial interface interaction $[12,14]$. It is known that different cell types use different mechanisms when attaching to different surfaces and as a rule, cells do not interact with the surface directly but via proteins secreted by them and adsorbed on the surface adhesive, forming their own nonorganized layer [15]. According to a "classical scheme", adhesive factors, like fibronectin and vitronectin are present in the serum adsorbed on the substrate and the adhesion is in fact an interaction with them. This interaction is ligand-receptor because the cells have specialized receptors (integrins) through which they identify the adsorbed adhesive proteins-ligands $[16,17]$. Guided by the substrate surface properties, conformational alterations of the adsorbed proteins possibly change their biological behavior [16]. In this context, the initial cellular interactions depend on the surface physicochemical properties such as the surface wettability, charges, heterogeneity, topography, roughness and presence of functional groups [15]. It is not clear why, but it is well-known that some materials with hydrophobic surface adsorb proteins in a way decreasing their native bioactivity [16]. Evidently, the adequate adhesive proteins adsorption is essential for the initial cell adhesion. In addition, it is known that the initial interface interaction between the cells and the contacting biomaterial mimics to some extent the natural adhesive interaction of cells and the extra cellular matrix. However, the cells not only interact with the adsorbed soluble matrix proteins, such as fibronectin and fibrinogen, they also tend to reorganize them in fibrils. This cellular activity depends significantly on different biomaterial surface parameters, such as hydrophilicity, chemical composition and charges [15]. Although the protein adsorption and cell/biomaterial surface interaction mechanisms are not fully understood, the surface physicochemical parameters known to influence these two phenomena could be summarized as follows $[9,12$, $14,15]$ :

(i) surface free energy and related parameters, hydrophilic/hydrophobic balance, polarity, water contact angle and its hysteresis,

(ii) surface charge and related electrostatic interactions,

(iii) type and mobility of the surface functional groups,

(iv) micro and nanotopography features and surface roughness $[14,18]$,

(v) thickness, density and adhesion of the modifying layer,

(vi) crystallinity [19].
The shape and size of the biomaterial particles also influence the cell recognition ability and interaction [20].

The effect of surface topography and chemistry on cellular response is of fundamental importance, especially where living systems encounter device surfaces in medical implants, tissue engineering and cell-based sensors. To understand these biological processes on the surfaces, there is a widespread interest in tailored surface-active materials produced by surface chemistry coupled with advanced patterning processes [21].

Most biomolecules have immense recognition power (specific binding) and at the same time demonstrate a tendency to physically adsorb onto solid substrate without specific receptor recognition (nonspecific adsorption). Therefore, to create useful materials for many biotechnology applications, interfaces are required that have both enhanced specific binding and reduced nonspecific binding. Thus, in applications such as sensors, the tailoring of surface chemistry and the use of micro and nanofabrication techniques became an important direction for the production of surfaces with specific binding properties and minimal background interference. Both self-assembled monolayers and polymer brushes have attracted considerable attention as surface-active materials [22].

Different surface engineering approaches to create biomaterials with improved biocontact properties are based on the relationship between the tissues, blood and other living matter contacting material surface properties and the interactions on the interface.

A variety of surface engineering methods is divided by Hoffman [21] into two main groups: physicochemical and biological. Examples of physicochemical methods are the acid etching/oxidation, ionizing irradiation treatments (various cold plasmas, ion or electron beams, and laser), photo-lithography, surface grafting of functional groups [23], based on well-known wet chemistry reactions. Plasma treatment is usually accompanied by so-called "surface reconstruction" tending to turn the surface back in its initial state. Therefore the plasma treatment is usually followed by chemical grafting or/and immobilization of biomolecules [22, 24-29].

Matrix proteins such as collagen and fibronectin, peptides or short peptide sequences such as RGD and GRGD as well as different growth factors are immobilized on the biomaterial surface besides chemical functional groups grafting and topographic features creation, to design a support mimicking the natural extra cellular matrix-specific features or functions [30-35]. This is the essence of the biological methods group including also simple physical preadsorption of proteins, peptides and/or growth factors, enzymes immobilization, and cell preseeding.

For a long time our research group has been developing polymer surfaces with controlled protein adsorption and initial cellular interactions potentially applicable in blood and/or tissue contacting devices, scaffolds for cell culture, and patterning of proteins. We present here examples of such biomaterials as well as their preparation approaches including some results from our investigations. 


\section{Bioinert Biomaterials}

The early stage of surface engineering is devoted mainly to bioinert material surfaces design, that is, such that do not cause any undesirable reactions, (foreign-body or inflammatory reaction, encapsulation, thrombi formation and blood coagulation) when in contact with living matter (tissue, cells, blood) inside or outside the human body. Such surfaces are still of interest for a variety of blood and/or tissue contacting devices, intraocular lenses, patterned supports for tissue engineering, micro fluidic devices, and biosensors. Most of them have been designed on the concept of creatinng low-adhesion and protein-repellent surfaces that have weak interactions with cells.

Long ago, Ykada et al. [36] theoretically predicted that there are two possibilities for the work of adhesion of polymer surface in aqueous media to approach to zero, that is, to be nonadhesive: one is to be super hydrophilic, that is water-like with water contact angle, $\theta$ approaching to 0 and the other is to be strong hydrophobic with surface tension, $\gamma$ approaching to 0 . This is the starting point in the development of strong hydrophilic or strong hydrophobic low-adhesion, protein-repellent biomaterials and biofouling release surfaces.

The creation of hydrophilic low-adhesive surfaces is relatively easy and the water-soluble (biocompatible) polymers immobilization on the surface is one of the possibilities. Such polymers could strongly adsorb water and the presence of high water content on the surface have been accepted as potential advance of the biomaterial regarding its similarity to the living matter and especially for providing minimal interface tension in contact with blood that can reduce the protein adsorption and cells adhesion [25, 37-39]. A variety of polymer surfaces: hydrophilic poly(ether urethane), sulphated polyethylene (PE), hydroxyethyl methacrylate and other hydrogel-coated surfaces $[9,40,41]$ have been designed to reduce protein, cell and bacterial adsorption at interfaces with biological tissues. Among them, PEG-coated surfaces confers protein and cell resistance with considerable success $[42,43]$. A comparative ESCA study of the protein adsorption on different strong hydrophilic surfaces: positively charged ( $N$-vinyl-pyrrolidone, NVP), negatively charged (Acrylic Acid, AA) and neutral (polyethylene glycol, PEG) clearly demonstrate the advantages of the neutral, strongly hydrophilic surfaces [44]. As it is seen from Table 1, the nitrogen content, originating from adsorbed BSA, is one order (and even more) lower on all PEG coated surfaces as compared to NVP- or AA- coated hydrophilic surfaces or to noncoated sulphated $\mathrm{PE}\left(\mathrm{PE}-\mathrm{SO}_{3} \mathrm{H}\right)$ and polyvinylchloride (PVC) surfaces. The results of ellipsometry measurements of the protein adsorption $[45,46]$ are similar. Therefore, attempts to PEG immobilized surfaces preparation have been made later by many researchers using different chemical and plasma chemical methods including hydrogel formation on the surface.

Photo-polymerized or photo-crosslinked coatings are one of the most popular. Such can be prepared by polymerization in situ of deposited on a substrate photo-reactive PEG resin. PEG acrylates or methacrylates are suitable for

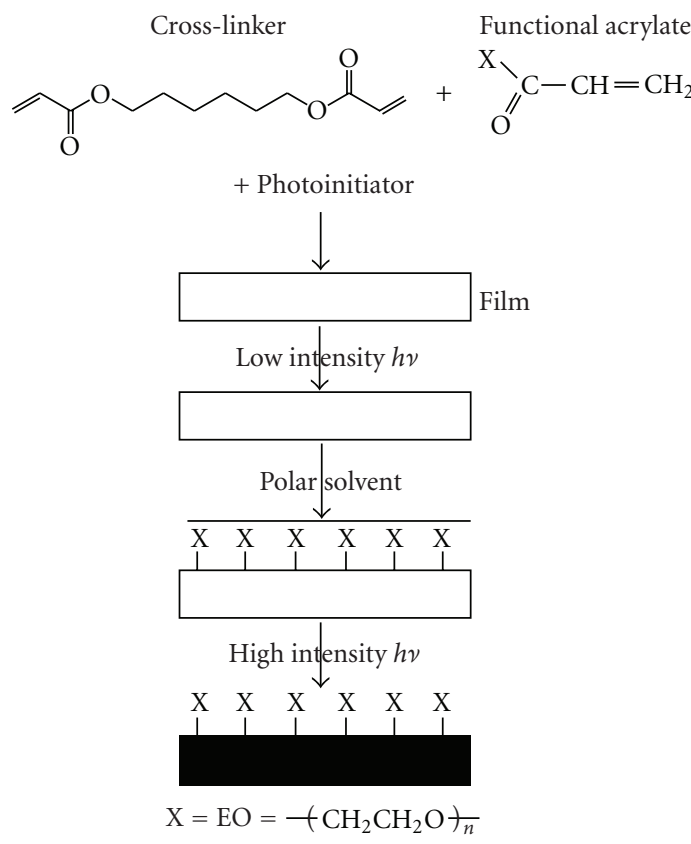

FIGURE 1: Two-step procedure for the photo-curing of a PEGacrylate layer for enhancement of the surface density of EO groups [50].

free radical polymerization, initiated by photo-initiators like benzophenones and thioxanthones $[9,45]$. A pioneer work $[43,45]$ describes a brush-like surface coating using monofunctional PEG-acrylates and a two-step UV polymerization to concentrate PEG chains on different polymer surfaces. The principle sketch of the two-step procedure for the photocuring of a PEG-acrylate layer for enhancement of surface EO groups' density is presented in Figure 1. The two-step procedure includes precuring at low UV dosage to obtain a gel-like low cross-linked PEG coating with high mobility and yet low water solubility. The following exposure in water leads to migration of polar EO groups to the water interface. Finally, the layer is subjected to a high UV dosage. The structural features of these PEG hydrogel coatings are presented in Figure 2. The two-step procedure enhances the EO content at the interface of about twice. Strong hydrophilic (water contact angle $<10^{\circ}$ ) protein repellent surfaces (protein adsorption below $0.05 \mathrm{mg} / \mathrm{m}^{2}$ ) could be prepared in this way on different polymers: PE, polyvinyl chloride, polystyrene, natural rubber, and polydimethyl siloxane [47-52]. R. Bischoff and G. Bischoff represent PEG hydrogel covering of polysiloxane tubing and tracheal prostheses preceded by plasma treatment [53]. Thin hydrogel formation by inferterbased photo-polymerization of dithiocarbamylated PEGs under UV irradiation or photo-polymerization has been reported by Lee et al. [54], Known and Matsuda [55] and Hahn et al. [56] aimed at photo-litographic patterning. Sequential formation of covalently bonded hydrogel multilayers thorough surface initiated photo-polymerization by using polymerizable PEG monoacrylates is described by Kizilel et al. [57]. 
TABLE 1: Cross-section corrected intensities of characteristic functional groups for various hydrophilic photo-polymeric films: Nvinylpyrrolidone (NVP), acrylic acid (AA) or polyethylene glycol mono-acrylates (PEG) on $\mathrm{PE}-\mathrm{OSO}_{3} \mathrm{H}$ and $\mathrm{PVC}$ after adsorption of bovine serum albumin (BSA).

\begin{tabular}{|c|c|c|c|c|c|c|c|}
\hline \multicolumn{2}{|c|}{$\mathrm{C}-\mathrm{O}-\mathrm{I}-\mathrm{CH}_{2}-$} & \multirow{2}{*}{$\frac{-\mathrm{COO}-/-\mathrm{CH}_{2}-}{0.27}$} & \multirow{2}{*}{$\frac{\mathrm{O}(1 \mathrm{~s}) /-\mathrm{CH}_{2}-}{0.45}$} & \multirow{2}{*}{$\frac{\mathrm{N} /-\mathrm{CH}_{2}-}{0.15}$} & \multirow{2}{*}{$\frac{\mathrm{N}^{+} /-\mathrm{CH}_{2}-}{0.04}$} & \multirow[t]{2}{*}{$\mathrm{Cl}(2 \mathrm{p}) /-\mathrm{CH}_{2}-$} & \multirow{2}{*}{$\frac{\mathrm{I}_{-\mathrm{CH} 2}-\left(\mathrm{cs}^{-1} \mathrm{eV}^{-1}\right)}{2706}$} \\
\hline $\mathrm{PE}^{-\mathrm{OSO}_{3} \mathrm{H}}$ & 0.57 & & & & & & \\
\hline NVP & 0.84 & 0.29 & 1.13 & 0.17 & 0.11 & & 1040 \\
\hline AA & 1.29 & 0.38 & 1.18 & 0.15 & 0.15 & & 1062 \\
\hline PEG550 & 1.08 & 0.28 & 1.39 & 0.04 & 0.02 & & 1402 \\
\hline PEG1900 & 2.06 & 0.46 & 1.47 & 0.03 & 0.01 & & 1145 \\
\hline PEG5000 & 1.81 & 0.30 & 1.23 & 0.03 & $>0.01$ & & 1226 \\
\hline $\operatorname{TMP}(\mathrm{EO})_{20}$ & 2.32 & 0.25 & 1.55 & 0.06 & $>0.01$ & & 1086 \\
\hline PVC & 0.72 & 0.21 & 0.41 & 0.13 & 0.04 & 0.23 & 1693 \\
\hline PEG550 & 0.80 & 0.20 & 0.64 & 0.09 & 0.02 & 0.18 & 1600 \\
\hline PEG1900 & 1.32 & 0.24 & 0.80 & 0.04 & 0.02 & 0.18 & 1332 \\
\hline PEG5000 & 2.20 & 0.30 & 1.35 & & 0.03 & 0.11 & 1051 \\
\hline $\operatorname{TMP}(\mathrm{EO})_{20}$ & 0.76 & 0.19 & 0.55 & 0.11 & 0.04 & 0.11 & 1694 \\
\hline
\end{tabular}

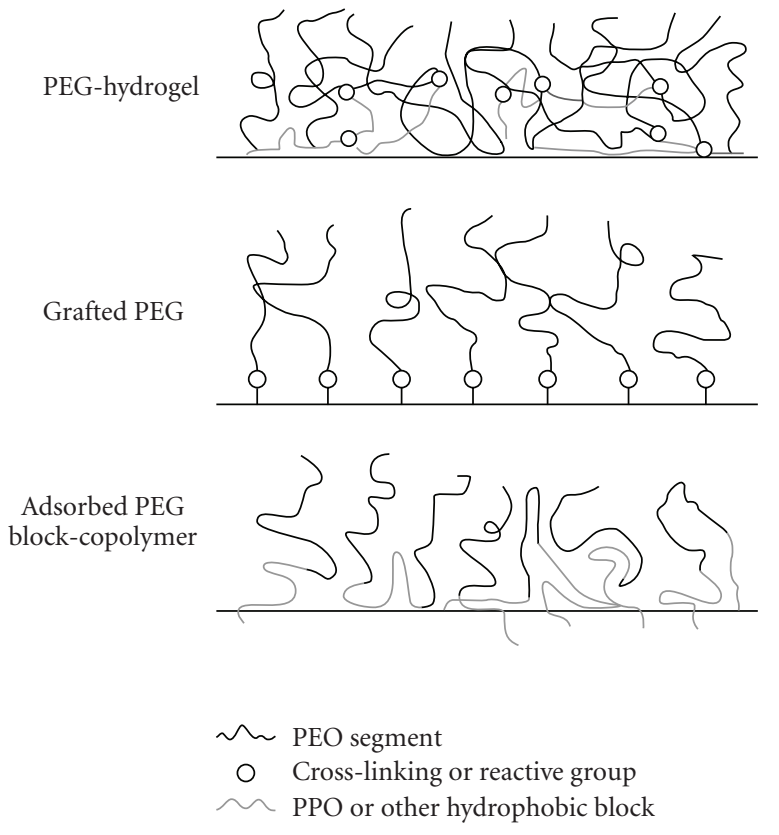

FIGURE 2: Schematic drawing that shows the structural features of PEG layers obtained by different coating: photo-polymerization, grafting and adsorption [50].

Ito et al. [58] performs photo-crosslinking immobilization of PEG on different surfaces and study subsequent interactions with proteins and cells, expecting that the hydrated nonionic surface would reduce the interaction with them. Photo-crosslinking immobilization is generally useful for the preparation of micropatterned surfaces because it uses a dry process. These researchers prepare photo-reactive PEG and carry out surface modification in the absence or in presence of a micropatterned mask. To assess nonspecific protein adsorption on the micro patterned surface, they adsorb horse radish peroxidase (HRP)-conjugated proteins and confirm a reduced protein adsorption by vanishingly small staining of HRP substrates on the immobilized regions. COS-7 cells have been cultured on the micropatterned surface. The cells do not adhere to the PEG-coated regions. In conclusion, photo-reactive PEG immobilized on various surfaces tends to reduce interaction with proteins and cells.

Chemical immobilization or grafting is another approach to create bioinert polymeric surfaces using suitable chemically reactive monomers such as hexaethylmetacrylate (HEMA), acrylic acid (AA), and PEG, among which PEG is most widely used. If the substrate surface is chemically reactive, the chemical immobilization or grafting can be performed directly. Otherwise, surface preactivation is necessary prior to the chemical immobilization or grafting, employing some wet chemistry methods to oxidize the surface or to introduce surface amino- or other functional groups, or ionizing irradiation using plasma, laser, and ion-beam.

A number of methods for covalent attachment of PEG to different polymer surfaces are known, requiring the employment of functionalized PEG (with derivative terminal $\mathrm{OH}$ groups), able to interact with a functionalized substrate surface. In case of strong hydrophobic and/or chemically inert polymers, surface preactivation is necessary by ionizing irradiation (plasma treatment, ion beam, laser, and HUV) or wet chemistry prior to the grafting the functionalized PEG. Figure 3 shows schematically the coupling procedure of PEG-aldehyde by Schiff base reaction with surface $-\mathrm{NH}_{2}$ groups as an example and Figure 2 shows the structural model of the PEG surface. This reaction is convenient for use in aqueous media where it could be driven to completion by addition of $\mathrm{NaCNBH}_{3}$, acting as a selective reducing agent for the imine product $-\mathrm{CH}=\mathrm{N}-$ in presence of aldehyde. In order to increase the surface density of PEG chains, the immobilization reaction can be performed under solution conditions close to the cloud point when the repulsion between the PEG chains is small. To induce clouding at lower reaction temperatures, "salting out" with potassium sulfate can be performed. PEG-aldehyde and PEG-epoxide grafting at optimal reaction conditions leads to 
the formation of surfaces with very low protein adsorptionbelow $0.05 \mathrm{mg} / \mathrm{m}^{2}$ (by ellipsometry) $[45,50,59]$.

Feng et al. [60] and Schlapak et al. [61] utilize PEG-amines for coupling with poly(N-hydroxysuccinimidil methacrylate) and Patel et al. [62] for coupling with silanized glass slides bearing aldehyde groups. Li et al. [63] graft living poly(ethylene oxide) to chloromethylated and crosslinked polystyrene and polypropylene substrates through the reaction of alkoxide with chloromethyl group.

Aldehyde groups bearing silanised surfaces could be grafted by $\mathrm{NH}_{2}$-terminated PEG and on the other hand $\mathrm{OH}$ containing surfaces can be immobilized with PEG-silanes. The second approach is used by Popat et al. [64], Piehler et al. [65] and $\mathrm{Xu}$ et al. [66] to improve the biocompatibility of nanoporous materials, biosensors and poly(acrylonitrileco-maleic acid) asymmetric membranes, respectively. Groll et al. [67] prepare and characterize ultrathin coatings from isocyanate-terminated star PEG prepolymers. To interrupt platelet adhesion, Choi et al. [68] and $\mathrm{Xu}$ et al. [69] immobilize PEG derivatives on poly(acrylonitrile-co-maleic acid) and polyurethane respectively.

Ko et al. [70], Sebra et al. [71] and Beyer et al. [72] immobilize PEG or its sulphonate onto preoxidized in ozone polymer surfaces. Acrylamide-coated surfaces have been created also by radical graft copolymerization on preoxidized in UV ozone plasma generator [73].

Goda et al. [74] prepare biofouling poly(dimethyl siloxane) (PDMS) with excellent surface hydrophilicity and good oxygen permeability by surface initiated radical graft photo polymerization of 2-metacryloil-oxiethylphosphatydil cholin (MPC) - biomimetic synthetic phospholipid polymer, containing phosphatydilcholin groups.

Quasi-irreversible adsorption opens another way to PEG and other molecules of interest, immobilization on different surfaces. High-molecular-weight copolymers of PEG or other molecules can be adsorbed irreversibly, attaching at multiple adsorption sites. Although the free energy of adsorption for each side may be relatively small, the attachment of a molecule to several sides leads to a multiplication effect, so that the total free energy of adsorption of a polymer becomes quite large. For this reason, polymers tend to be adsorbed very strongly in many cases. One approach to achieving firmly attached PEG coatings at negatively charged surfaces is to physically adsorb a graft copolymer of PEG and polycation such as polyethylene imine (PEI), for example. Their structural features are shown in Figure 3 and they also demonstrate very low protein adsorption (below $\left.0.05 \mathrm{mg} / \mathrm{m}^{2}\right)$ [75].

Dextran has recently been investigated as an alternative to PEG for low protein-binding, cell-resistant coatings on biomaterial surfaces [76]. Although antifouling properties of surface-grafted dextran and PEG are quite similar, the multivalent properties of dextran are advantageous when high-density surface immobilization of biologically active molecules to low protein-binding surface coatings is desired. The preferred methods of dextran immobilization for biomaterial applications should be simple with minimal toxicity. In this report, a method is described for covalent immobilization of dextran to material surfaces, which involves low residual toxicity reagents in mild aqueous conditions. With dextran-based surface coatings, it will be possible to develop well-defined surface modifications for better performance of long-term biomaterial implants.

Thanawala and Chaudhury [77] use acrylamid perfluoroether to create high hydrophobicity and antiadhesive properties of polymeric biomaterials.

The existing surface engineering strategies often require the presence of specific surface functional groups and extensive optimization, and they have limited capacity to be used for modification of variety materials. Thus, there is an ongoing need for versatile immobilization strategies that are capable of robustly anchoring not only PEG but also other antifouling polymers onto variety of medically relevant material surfaces or to create other types bioinert surfaces. Ober et al. [78-82] investigate different possibilities for creating low-energy low-adhesive nonbiofouling surfaces using mainly fluorine containing co-polymers.

Various irradiation methods, and especially both cold plasma treatment and coating are widely used for preactivation of different polymer surfaces with a creation of desired for following chemical coupling surface functionality as well as for creation of thin layers with altered hydrophilic/hydrophobic balance, chemical composition or topography and structuring. Using plasma of different gases and optimizing the operation conditions it is possible to input different functional groups on the surface or to create thin surface coating with varied properties. Figure 4 shows a simple sketch of the chemical composition of different radio frequency (RF) plasma discharge deposited films, based on the results from X-ray photoelectron spectroscopy (XPS). Comparative study of such plasma deposited films [83-85] indicate that both, strong hydrophobic silicon and strong hydrophilic PEG surfaces is characterized by very low protein adsorption, weak complement system activation and low cell and platelet adhesion that is in a compliance with the prediction of Ykada et al. [36].

Sioshansi et al. $[86,87]$ find that the argon ion implantation of the polymer surface reduces significantly the friction and biofouling of the catheters. The thrombogenicity and endothelial cells adhesion onto artificial vascular grafts could be also controlled by argon ion implantation [88].

Husein et al. $[89,90]$ establish that the ion implantation on polysiloxane surface from plasma source leads to an increase of the surface silanol groups similar to that when the same polymer is plasma or argon ion beam treated. Uncustomary differences in the cell sensitivity to similar on chemical composition polysiloxane surfaces, obtained by different irradiation methods are observed by some researchers [91] attributed to differences in the surface energy, especial electron structure and the corresponding electrical properties of the surface layer.

Bhushan et al. [92] prepare (by gas-phase deposition) ultra thin fluorosilane films to control the biomaterial surface hydrophobicity and to reduce or prevent the protein adsorption and cell interactions, the last ones of critical importance for the work of some biomedical nanodevices.

Surface topography is accepted now as a parameter influencing the wettability and hence the protein adsorption 


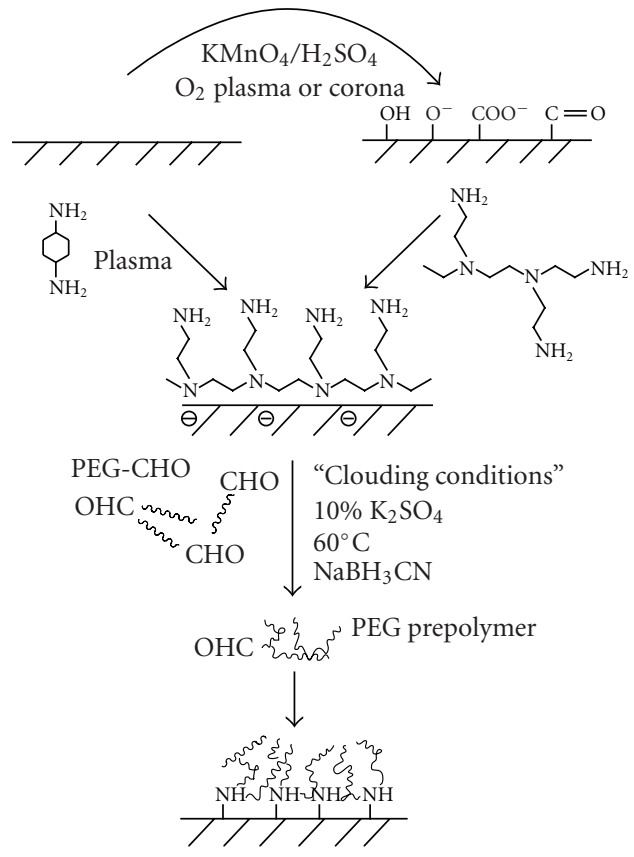

FIGURE 3: Grafting of PEG by the Schiff base reaction between PEG$\mathrm{CHO}$ and surface- $\mathrm{NH} 2$ on polymer surfaces aminated in various ways, for example by treatment in di-amino-cyclohexane $(\mathrm{DACH})$ plasma or by deposition of polyethyleneimine (PEI) on preoxidated polymer surface [50].

and biocontact properties of the biomaterials. Sear et al. [93] study surface texturing and collagen coating of biomaterials in respect to fibrosis inhibition and demonstrate that the biomaterial surface texturing is as important as the matrix proteins in the reduction of fibrosis and inflammatory reactions. Some types of surface texture almost eliminate the fibrous capsules formation whereas other inhibits their collaps [94].

\section{Surface Engineered Biomaterials for Blood-Contacting Devices}

The surface design of biomaterials for blood-contacting devices is of special interest and different approaches to creation of such with improved thrombo-resistance are described in a number of reviews $[95,96]$. Different concepts are employed in the creation of biomaterials with improved blood contacting properties: physicochemical (zero critical surface tension or interfacial-free energy), micro heterogeneous surfaces (polymers with micro phase separated structure and segmented polyurethanes), simulation of blood vessel properties (surfaces with hydrophilic nature and high mobility, negatively charged surfaces), utilization of biologically active molecules (sustained release of heparin; heparinized surfaces), and biomembrane-like surfaces composed of polymer and phospholipids. However, the regulation of blood-biomaterial surface interaction is difficult and the many researches based on the abovementioned concepts have partial success.

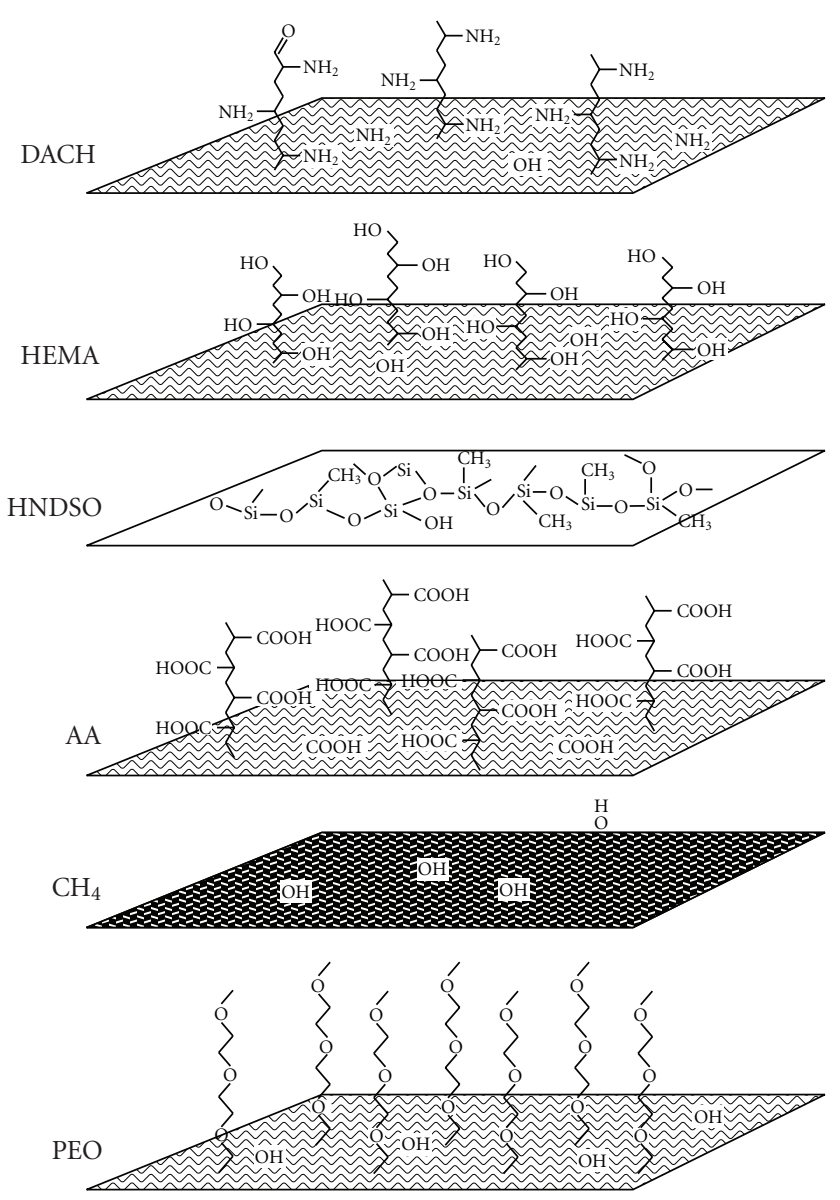

FIgure 4: Chemical composition of plasma deposited polymer films: diaminocyclohexane (DACH), hydroxyethylmetacrylate (HEMA), hexamethyldisiloxane (HMDS), acrylic acid (AA), methane $\left(\mathrm{CH}_{4}\right)$ and polyethylene oxide (PEO) [50].

It is experimentally established that an increase in the surface hydrophilicity decreases the cell adhesion. However, low cell adhesion does not certainly mean prevention of the biological activation. Some researchers $[9,97,98]$ have established low platelet adhesion to strong polar surfaces and high thrombin activation and coagulation.

Most cells have negatively charged surfaces and therefore their electrostatic attraction or repulsion is of importance [9, 99-101]. Cell proliferation is also influenced by the biomaterial surface charge and hydrophilic/hydrophobic balance [102].

Biomaterials with micro-domain surfaces on which adsorbed proteins are able to self-organize accordingly the surface micro heterogeneity are another group bioinert biomaterials. It is demonstrated that the low-trombogeneity of block co-polymers of the type ABA with hydrophilic/ hydrophobic micro-domain structure is due to a significant oppress of adhering platelets activation [103-106]. Typical representative of this group are the segmented poly(ether urethanes) [107].

Low platelet adhesion has been found on acrylamid or other hydrogel coatings as well as on collagen coatings 
onto corona preactivated polymer surfaces, reducing fibrosis around the biomaterial implants as proved at experiments with animals in vivo [108-111].

Mirzadeh et al. [112-118] create super-hydrophobic polymer surfaces by laser treatment and turn them into hydrophilic ones grafting hexamethylacrylate (HEMA) after their preactivation by $\mathrm{CO}_{2}$-pulse laser treatment. The data from in vitro investigations demonstrate significantly reduced platelet adhesion and aggregation on the two type modified surfaces but the best regarding the blood compatibility appears to be the super-hydrophobic one.

Regarding blood compatible materials, heparinized surfaces seem to be one of the most promising approaches and a number of ways to surface immobilization of heparin have been described $[9,119]$. Heparin, which together with other sulphated gluco-amino-clucans naturally exists on the intra vascular endothelial cells, is a potent anticoagulant. Although graphitic carbon has been known and used as a biomaterial for a long time, the excellent biocompatibility of diamond-like carbon (DLC) films has been addressed only in a few cases. Steffen et al. [120] anticipate the combination of bioinert DLC films and surface immobilized bioactive biomolecules with antithrombogenic properties, such as the polysaccharide heparin, as a straightforward concept to optimize haemocompatibility of a wide variety of materials (vascular grafts, etc.), this strategy has been applied at polytetrafluorethylene (PTFE), poly(dimethyl siloxane) (PDMS), and polystyrene (PS). The DLC films were deposited on polymer surface by an energetic acetylene plasma beam and subsequently exposed to ammonia plasma before heparin was covalently coupled to such functionalized surfaces by an end-point attachment method. Ion-beam radiation of siloxane rubber at relatively high energy (50-150 keV) alters its surface chemical composition and wettability, leading to lower thrombus formation on the ion implanted haemodialysis catheters, proved in vivo experiments with animals [121-124]. Many basic concepts for development of blood compatible surface engineered polymeric biomaterials are described in the literature but the perfect nonthrombogenic material has never been obtained. The future trend is toward a combination of these concepts and hybridization of artificial materials and biological molecules.

\section{Bioactive Biomaterials}

Bioactivity is a necessary attribute of the current biomaterials for in growing implants, some biosensors, tissue engineering and regenerative medicine. The bioactive biomaterials establish specific interactions in contact with living matter (tissue, blood, cells) and mimic some human functions. They are actively interacting and integrating with their biological environment [125].

The principal goal of the regenerative medicine is to promote tissue regeneration and healing after injury or disease, that can be achieved through a delivery of cells and/or factors in tissue engineered scaffolds designed to provide a biomimetic microenvironment conductive to cell adhesion, proliferation, differentiation, and host tissue integration [126, 127].

Currently, most scaffolds provide a three-dimensional environment in which tissue can grow and develop, so that to be able to reproduce the functions of the tissue that it is intended to replace $[128,129]$. Now scaffolds are being developed that either mimic the extra cellular matrix or the complete hierarchical structure of the tissue [130]. A variety of natural and synthetic biodegradable or biocompatible polymeric scaffolds is fabricated in a form of solid foam, nanofibrous matrix, microspheres, or hydrogel to provide an optimal microenvironment for cell proliferation, migration, and differentiation and guidance for cellular in-growth from host tissue. The scaffolds are further surface engineered to provide an extracellular matrix mimicking environment for better cell adhesion and tissue in-growth and in addition, to release bioactive molecules, such as growth factors, DNA, or drugs, in a sustained manner to facilitate tissue regeneration [131].

Evidently, the cell/biomaterial interaction is of key importance for all bioactive biomaterials and the knowledge about its mechanism can guide the surface engineering in the development of biomaterials with an optimal bioactivity.

\section{Cell/Biomaterial Surface Interaction}

The cell/biomaterial interaction is a complicated phenomenon and despite the enormous efforts of many researchers, its mechanism remains not fully understood $[12,15]$. It is well-known, that different cell types use different attachment mechanisms to different surfaces but any way the cell attachment is mediated by deposition of adhesive proteins secreted by themselves. The initial interface interaction when cells contact biomaterial surface resemble to some extent the natural adhesive interaction of the cells with their extra cellular matrix. In addition, the cells not only interact with the adsorbed soluble matrix proteins, such as fibronectin and fibrinogen, they also tend to reorganize them in fibrils. This cellular activity depends strongly on the physicochemical properties of the biomaterial surface, such as hydrophylicity $[9,15]$, steric hindrance, the existence of a "conditioning layer", surface chemical composition and charge, surface topography and roughness [132]. Many chemical functional groups, such as hydroxyl, carbonyl, carboxyl, and amine, are important for the fate modulation of the attached cells [133]. For example, the macrophages ability to form giant multinuclear cells (granular reaction) on some hydrogel surfaces correlates with the presence of some functional groups. The macrophages joining probability decreases in the following row [134]:

$$
\begin{gathered}
-\mathrm{N}\left(\mathrm{CH}_{3}\right)_{2}>-\mathrm{OH}>-\mathrm{CONH}->-\mathrm{SO}_{3} \mathrm{H} \\
>-\mathrm{COOH}(-\mathrm{COONa}) .
\end{gathered}
$$

Similar interaction hierarchy is observed at cell incubation onto functionalized surfaces at which the cell attachment and growth decrease in the following row [135]

$$
-\mathrm{CH}_{2} \mathrm{NH}_{2}>-\mathrm{CH}_{2} \mathrm{OH}>-\mathrm{CONH}_{2}>-\mathrm{COOH} \text {. }
$$


Studying a number of model surfaces Altancov [15] concludes that the hydrophilic surfaces support the cell adhesion and proliferation, cell growth and the organization of the focal adhesion complex delivering the signal via integrin receptors. An optimum interaction with cells usually appears at moderate hydrophilicity (water contact angle of $\sim 50^{\circ}-$ $65^{\circ}$ ). The synthesis and organization of fibronectin matrix by cells is better on surfaces bonding weakly fibronectin and other matrix proteins. The conformation of the adsorbed adhesive proteins plays also an important role in the adhesive interaction on strong hydrophilic noncharged surfaces [15, 75]. The shape and size of biomaterial surface structure can to control the cell proliferation and orientation [136].

\section{Surface Engineered Biomaterials via Physicochemical Modification}

In general, surface properties of implantable biomaterials dictate protein adsorption and behaviors with concomitantly determining of the cellular interactions. In most cases, specific cellular interactions are required for the formation of a desired tissue. A way to promote implant, scaffold and engineered tissue integration is to design the surface chemical composition and topography of the biomaterials to specifically enhance tissue integration [137-142]. The scaffold surface can be functionalized either by physical adsorption or chemical modification [143]. The surface chemical modification employs different organic chemistry reactions, ionizing radiation treatments (plasmas, ion-beams, and laser) and coatings, immobilization of biomolecules or the combinations of different approaches to control the surface characteristics of the biomaterial.

As mentioned above, despite that the reason is not fully understood, the moderate hydrophilic surfaces are preferred by the cells. Therefore, simple hydrophilization of hydrophobic surfaces is one the main approaches to improve their interaction with cells. The adsorbed adhesive proteins conformation, together with the possibility for easy detachment from the hydrophilic substrates [16] seems to be other important factors, because the cells "try" to organise their own matrix on the biomaterial surface [144-146]. The most physicochemical treatments lead in fact to some surface hydrophilization. PS treated with sulphuric acid or in glow discharge plasma, characterises with increased number of charged groups on the surface that improves the attachment and growth of many types of cells [147]. The naturally nonadhesive polymer poly(2-hydroxyethyl metacrylate) (PHEMA) demonstrates improved adhesion and proliferation of endothelial cells after sulphuric acid treatment [148]. RF cold plasma treated poly(ethylene terephthalate) (PET) surface demonstrate an improved attachment and spreading of fibroblasts and mioblasts [149]. PEG-coated surfaces are usually prepared to be protein repellent, antifouling and bioinert. But surprisingly, PEG coatings prepared by quasiirreversible adsorption of a graft copolymer of poly(ethylene imine) (PEI) and PEG (PEI-PEG) demonstrate an unusually good cellular interaction: cell spreading, proliferation, adhesion, "early" and "late" matrix formation $[75,144]$. The
PEG coatings prepared in this way are strong hydrophilic (equilibrium water contact angle $<10^{\circ}$ ) and characterize with very low adsorption of HSA, IgG, Fng, Fn, C3 and Cq1 $\left(<0.05 \mathrm{mg} / \mathrm{m}^{2}\right.$ by ellipsometry) as shown in Table 2 . In general, for such surfaces good biocompatibility is expected, in the sense of bioinertness but low cellular interactions. The observed unexpected good interaction with fibroblasts despite the strong hydrophilicity and very low protein adsorption is thought to be due to a specific PEG layer structuring providing an optimal conformational freedom for the protein reorganization [144].

Cold plasma obtained in low-pressure glow discharge has been often used to activate polymer surface, including siloxane membranes $[25,27,29,150]$ for further grafting of suitable monomers like acrylic acid (AA), hydroxyethylmetacrylate (HEMA), and so forth. aimed at improvement of its interaction with living cells. On the other hand, ion-beam without following grafting $[151,152]$ is known as other possible way to improve biocontact properties of polysiloxanes $[153,154]$. Plasma based $\mathrm{Ar}^{+}$beam performed in $\mathrm{RF}(13,56 \mathrm{MHz})$ low-pressure with a serial capacitance can be employed for surface modification of PDMS to combine some advantages of both: ion-beam and plasma treatment, namely the durability of the modifying effect of the ion-beam with the simplicity of the plasma as compared to ion-beam equipment [155]. The presence of a serial capacitance ensures arise of an ion-flow inside the plasma volume directed toward the treated sample and the discharge power vary ensures varied ion-flow density. A partially mineralized surface layer, similar to that obtained after a conventional ion-beam is the result of plasma based $\mathrm{Ar}^{+}$beam treatment of PDMS surface as proven by XPS analysis and contact angle measurements [156, 157]. Plasma based $\mathrm{Ar}^{+}$beam treatment transforms the initially strong hydrophobic PDMS surface into a durably hydrophilic one, mainly due to raising of the polar component of the surface tension, this effect being most probably due to an enrichment of the modified surface layer with permanent dipoles of a $[\mathrm{SiOx}]$-based network and elimination of the original methyl groups [156]. Such modification is accompanied also with altering of the surface topography and roughness [157] and leads to significant improvement of the initial cell adhesion not only in presence but also in absence of precoated fibronectin $[156,157]$.

Bearing radicals and hence activating PDMS surface, $\mathrm{Ar}^{+}$beam treatment opens a way to further grafting of suitable monomers. The acrylic acid (AA) grafted, in this way preactivated PDMS surface, is moderate hydrophilic (water contact angle of $62-73^{\circ}$, depending on the AA grafting density). The initial adhesion of human fibroblasts to AA grafted surfaces is significantly higher as compared to that on nonmodified PDMS surface but only in presence of precoated fibronectin $[156,157]$.

Oliveira et al. [158] have developed a new methodology to obtain bioactive coatings on bioinert and biodegradable polymers that are not intrinsically bioactive. Three types of materials have been used as a substrate: high molecular weight PE and two starch-based blends: starch/ethylene vinyl alcohol and starch/cellulose acetate. Blowing agent has been 
TABLe 2: Protein adsorption $\left(\mathrm{mg} / \mathrm{m}^{2}\right)$ as measured by ellipsometry.

\begin{tabular}{lcccccc}
\hline Surface & $\mathrm{A}_{\mathrm{HSA}}$ & $\mathrm{A}_{\mathrm{IgG}}$ & $\mathrm{A}_{\mathrm{Fgn}}$ & $\mathrm{A}_{\mathrm{Fn}}$ & $\mathrm{A}_{\mathrm{C} 3}$ & $\mathrm{~A}_{\mathrm{Clq}}$ \\
\hline Silika & 0.35 & 1.10 & 2.9 & 1.90 & 3.10 & 1.90 \\
PEI/PEG1500 & - & $<0.05$ & $<0.05$ & - & - & - \\
PEI/PEG6000 & $<0.05$ & $<0.05$ & $<0.05$ & $<0.05$ & $<.05$ & $<0.05$ \\
PEI/PEG12500 & - & $<0.05$ & $<0.05$ & - & - & - \\
\hline
\end{tabular}

HAS: human serum albumin; IgG: immunogammaglobulin; Fgn: fibrinogen; Fn: fibronectin; C3: complement component; C1q: complement component.

used to prepare 3D porous architectures. Three type baths have been developed in order to produce the newly proposed auto-catalytic Ca-P coatings.

If the scaffold is bioactive gel-glass or an inorganic/organic nanocomposite, surface $\mathrm{OH}$ group will be present because of Si-OH (silanol) bonds, and many polymers also have high surface $\mathrm{OH}$ content (e.g., $\mathrm{COOH}-$ ) that can be functionalized with APTS. Materials with $\mathrm{OH}$ groups will therefore attract proteins when implanted in vivo [159].

\section{Surface Engineered Biomaterials via Biomolecules Immobilization}

Surface modification of implant devices by immobilization of biological molecules is discussed in a number of reviews, for example [160]. In natural environment, cells grow onto substrate consisting different proteins and polysaccharidesextra cellular matrix (ECM). The last one not only provides mechanical support for the cells but also interacts directly with them and influences their growth, migration, morphology and differentiation. Surface modification of synthetic polymers that have suitable mechanical parameters and processability with biofunctional species providing similar to the natural ECM interaction allows combining advances of the synthetic and natural materials and resembling the interactions with specific ECM ligands [161]. To provide a support more closely resembling the natural ECM, in addition to the chemical functional groups, matrix proteins like collagen, fibronectin, and so forth could be immobilized on the synthetic polymeric material surfaces $[162,163]$. This is the nature of biomimetic approach, that is, of the group of the biological methods aiming at resembling of some specific structural or functions features of the natural extra cellular micro environment [164]. This group of methods includes simple protein preadsorption, enzymes immobilization, and cell preseeding. However, it is not yet clear which proteins and how they affect the cell response. Interactions between peptides and scaffolds can result in completely different surface chemistry, topography, surface energy and charge. They can also lead to conformational changes in the peptide structure, which is usually undesirable. Proteins are usually adsorbed or bonded onto material surfaces in solution by immersing the material in phosphate buffer saline (PBS) containing proteins [165].

Various strategies have been attempted to immobilize biomolecules or small biological motives onto the surfaces of synthetic biomaterials devoid of active functional groups [166]. Physical adsorption is one of the methods for preparation of surfaces with well-defined properties that do not rely on chemical processing. It utilizes weak nonspecific intermolecular interactions between the surface and peptide species involved such as hydrogen bonding, hydrophobic interactions, Van der Waals forces, and weak valence electron interactions. To obtain biomimetic materials, surfaces can be simply coated with biomimetic peptides or another material possessing active functional groups, for example, poly-Llysine (PLL) that can be subsequently used to chemically react with oligopeptides. Materials can also be coated with hybrid molecules such as PLL-RGD polymer-peptide molecules, which can be physically adsorbed to material surfaces. While physical adsorption is an effective way to immobilize biomimetic peptides to the surface of materials, coating only provide a transient modification of the material surface. The inability to control the peptide conformation and orientation upon the adsorbing substrate, peptide desorption or wash-off, diffusion kinetics, and inaccessibility to large molecules on the material surfaces are deficiencies of this method. Substances including PLL, collagen and cell adhesive proteins such as fibronectin, laminin or vitronectin have been adsorbed onto the surface of polymeric matrix to promote cell attachment $[167,168]$.

In order to fabricate biomimetic materials that can withstand long-term survival, a stable immobilization of such biomolecular motives to the substrate surface is critical to maintain the bioactivity and ultimately proper functioning. Substrate-immobilized biomimetic oligopeptides should be able to withstand the contractile forces extended by adhered cells upon the biomaterial surface during initial cellular attachment and resist the internalization by cells [166]. Covalent binding of functional biomolecules is necessary to provide a more stable cell adhesive stratum that can be achieved by direct or indirect chemical immobilization of collagen, gelatin, heparin, hyaluronic acid, short peptide sequences, originating from cell adhesive proteins such as the arginine-glycine-aspartic acid (RGD) or YIGSR, and sugar moieties such as galactose or lactose, have been grafted onto polymer surfaces to modulate cell-matrix interactions $[169,170]$.

Direct immobilization via chemical methods; however, can be accomplished when surface reactive groups are presented, which is not always the case with certain materials. Plasma-treated surfaces have been used to introduce active functional groups to biomaterial surfaces for direct covalent immobilization of biomolecules. Plasma treatments under a wide range of reacting gas types (ammonia, nitrogen, hydrogen, oxygen, and ozone) have been employed to be introduced various functional groups (e.g., carboxyl, 
hydroxyl, carbonyl, ether, peroxide, and amine) of material surface. Karkhaneh et al. [171] modify the chemically inert PDMS simultaneously with acrylic acid (AA) and 2-hydroxyethyl methacrylate (HEMA) employing so-called "two-step plasma treatment", followed by collagen immobilization and study the cellular response to the modified surfaces. Such surface design significantly increases the number of the adhered and proliferated cells.

In plasma-induced graft polymerization, material surface is bombarded with energetic gaseous species (ions, electrons, free radicals, and low-energy photons) whose energy is transferred and dissipated thorough the solid by a variety of chemical and physical processes. The result is surface functionalization with amine, peroxide, carboxyl, and so forth. groups that can be utilized in a further chemical immobilization of biomolecules via graft polymerization [172-174]. Graft polymerization can result in producing specific surface properties for use in various applications to improve cell adhesion and spreading, to enhance the surface wettability and improve material biocompatibility. Graft polymerization can also be used to treat defined surface areas by using photo-masks or resists [175].

Plasma polymerization can be used to produce surfaces that are either nonadherent or keratinocyte adherent for tissue engineering of skin [176]. This technique is used to produce a background surface coated with octadiene, which is nonadhesive for the majority of cells. Onto this is placed a template of the letters "TONY" coated with acrylic acid. The placed on this surface cells adhere to the acrylic acid-coated surface but failed to adhere to the octadiene-coated surface. Thus, biomaterials can assist the transport and delivery of keratinocytes to a wound bed [177].

The covalent attachment of biologically recognizing molecules to the surface of some biomaterials is hampered by the lack of surface chemical reactivity. To overcome this problem, researchers utilize many different approaches to create functional groups on the surface of biomaterials to support covalent bonding of biological recognition motives, that is, they preactivate biomaterial surface employing different organic chemistry methods or ionizing radiation treatment (cold plasmas of different gases, ion-, laser beams, etc.). For example, Li et al. [178] immobilize RGD peptide fragments on the PDMS surfaces for cell culture indirectly. The immobilization procedure includes preliminary photochemical grafting of NHS-groups on the PDMS surface, followed by RGD bonding to the NHS groups via coupling reaction in presence of bi-functional photocross-linker. As compared to other methods for peptides bonding to PDMS, this one is relatively easy, effective and free of organic fouling of the PDMS surface. This approach could be employed for coupling other peptides or proteins to most polymeric materials. Such surfaceengineered materials are stable during autoclaving and UV treatment, which make them suitable for repeat use at cell culture.

A liquid phase modification of PDMS micro fluidic channels includes an acid $\mathrm{H}_{2} \mathrm{O}_{2}$ solution oxidation and following silanation reaction, using pure silane reagents. Two different functional groups, PEG- and amino- have been included in this way on the PDMS surface for the protein adsorption passivation and biomolecules coupling, irrespectively. Biomolecules immobilized biomaterials could be used for cell seeding and incubation [179].

Carbodiimide chemistry is high effective and widely used method to covalently immobilized biomimetic peptides onto various carboxylated biomaterial surfaces via stable amide bonds [180-183]. Carbodiimides are widely used for carboxyl group activation via formation of mediating high reactive $\mathrm{O}$-acylisocarbamide compounds. These active species interact with amine nucleophyls forming stable amide bonds [184]. Unfortunately, this method is not high enough selective. The biomimetic peptides often contain reactive functional groups presenting within the constituent amino acid side chain (e.g., carboxyl and guanidine groups) that leads to unwanted side reactions. $N$-hydroxysuccinimide (NHS) is often used to assist the carbodiimide coupling by forming an active ester intermediate via condensation of surface carboxylic acid groups and NHS. The ester derivative is less prone to hydrolyses, it can be prepared in advance and stored and used as an activated species in situ (e.g., in the presence of the amine nucleophile) without the risks of the unwonted reactions. The NHS-reactive ester intermediate is susceptible to nucleophilic attack by primary amines and results in the formation of stable amide bonds between the biomaterial surface and the $\mathrm{N}$-terminus of the biomimetic peptide.

The immobilization of biomolecules to hydroxyl groups presenting on various biomaterial surfaces can be easily and directly accomplished with the use of highly reactive sulphonyle chlorides. Hydroxyl-containing surfaces can also be preactivated with tresyl chloride [185-187] to yield sulfonated surfaces that can readily undergo nucleophylic attack by primary ammines, thiols and imidasole groups [188-190]. Aminated surfaces can be effectively immobilized with bioactive peptides by reacting the solid surface with homobifunctional linkers, such as glutaraldehyde, disuccinimidil glutarate, or phenylene diisothiocyanate [191193] via the N-terminus of the peptide. Carboxyl-terminus immobilization can also occur via carbodiimide-mediated immobilization of aminated surfaces. PE covered with cellular matrix proteins and cell-membrane antigens characterises with improved human endothelial cells adhesion and proliferation [194]. Surface functionalized micelles and shell cross-linked nanoparticles are research objective of Wooley group [195-198].

Collagen is a major structural component forming the natural ECM of connective tissue and organs [199]. Surface immobilization of collagen is one of the most established methods for endowing cell adhesive properties to the scaffolds. Poly(lactic acid) (PLA) and PLGA scaffolds chemically grafted with collagen after plasma treatment [200] and PLA scaffolds collagen immobilized by conjugation reaction via grafted poly(methacrylic acid) [201] show enhanced cell adhesion, spreading and growth. Collagen can be deposited on some surfaces from aqueous solution, for example, by using dip-pen nanolithography, to form nanoscale patterns with some control on the assembly for bone tissue growth [202, 203]. 
The direct covalent bonding of biomolecules to chemically inert polymer surfaces such as PE, PTFE, PDMS, is difficult and surface preactivation, followed by a multistep bonding procedure is necessary. For example, preactivation of PTFE by plasma treatment opens a way to a multistep procedure for peptide immobilization on its surface [204]. Plasma based $\mathrm{Ar}^{+}$beam treatment of PDMS also opens a way to its biofunctionalization by a multistep procedure including acrylic acid (AA) grafting and flexible PEG-spacer coupling prior to a collagen immobilization by peptide synthesis reaction. AA grafted PDMS surfaces are reacted with PEG bearing two terminal $\mathrm{NH}_{2}$-groups. A known peptide synthesis reaction is used for the immobilization of collagen, type I on the AA grafted and PEG spacer coupled samples. Surface chemical composition, wettability, topography and roughness are controlled on every stage of the multistep procedure by XPS analysis, contact angle measurements and atom force microscopy (AFM) observations. Collagen immobilization via flexible spacer improves significantly the cellular interaction on the scarcely adhesive PDMS surface, this effect depending on the length of the PEG chain. This multistep procedure to biofunctionalization of strong hydrophobic chemically inert polymers has a potential to be used whenever need arises to control cellular interaction with the surface, for example cell culture, tissue engineering, biointegrating biomaterials.

Collagen's immunogenicity, due to its various biological functions, limits some applications. Gelatin is a good alternative for collagen because of absence of antigenity and easy of handling at high concentrations. Gelatin immobilized porous scaffolds (by physical entrapment and chemical cross-linking of the gelatin) show significantly enhanced surface properties for attachment, proliferation and osteoblasts ECM deposition [205].

Controlled deposition of ultra thin layers of silk and collagen by exploiting self-assembly can be performed using modified layer-by-layer techniques. Collagen has been deposited in ultra thin film format from aqueous solution based on hydrophobic interactions [206]. In addition, spray coated and deposited collagen films with entrapped drugs or cell growth factors have been reported [207]. An all-aqueous, stepwise deposition process, where control of silk structure locks in the formation of physical cross-links ( $\beta$-sheets) determining the coating stability is the approach of Chen et al. [208] for silk layer deposition. Layer-by-layer techniques are widely used to form polymer-layered surfaces/structures of biologically functionalized coatings. Usually, the primary driving force in more traditional layer-by-layer assembly is the electrostatic interactions between oppositely charged polyelectrolytes that form interpenetrated layers when the substrate is immersed in an alternating fashion in two solutions. For collagen and silk, the driving force is primarily hydrophobic. The nanoscale silk-layered biomaterials are stable under physiological conditions and support human bone marrow stem cell adhesion, growth, and differentiation, and the incorporation of small or large molecules [209]. Since the ultrathin layers are stabilized by $\beta$-sheet physical cross-links, no post processing chemical cross-linking is required to stabilize the materials and the thin films.
Silk proteins coating onto different biomaterial substrates for cell culture and tissue engineering applications have been reported, including poly(D,L-lactic acid) films, twoand three-dimensional polyurethane scaffolds, and twodimensional poly(carbonate-urethane). Methanol treatment of the silk coatings induces the structural transition to the $\beta$-sheet and stabilizes the coatings [210-213]. Silk fiber composites have been optimized for surface chemistry and architecture, seeded with human adult bone marrow derived mesenhymal stem cells or fibroblasts, and cultivated in vitro under static or complex mechanical forces in specialized bioreactors to simulate a knee-like environment $[214,215]$.

Hyaluronic acid (HA) is nonsulfated glycosoamineglycan that is a major substance of the gel-like component in the extra-cellular matrix of connective tissues. HA is capable of specific cell interaction via the CD44 receptor, which promotes wound healing and induces chondrogenesis. Therefore, HA has been chemically and physically incorporated into various tissue engineering scaffold matrices. HA modified chitosan-gelatin composite scaffolds increase the adhesion of fibroblasts [216] and HA modified PLGA scaffolds support the growth of chondrocytes with maintenance of its original phenotype, showing great potential for cartilage tissue engineering [217].

The sugar galactose has been utilized in scaffolds for liver tissue engineering. Porous scaffolds immobilized with galactose demonstrate improved hepatocyte attachment, viability and metabolic functions such as release of lactate dehydrogenase (LDH), albumin secretion and urea synthesis. Perfusion culture of hepatocytes with galactose-derivatized PLGA scaffolds further improves viability and functional activity of the cells $[218,219]$.

Immobilization of short chain peptide derivatives from the cell adhesive proteins onto the polymer surface can be a much more effective strategy rather than immobilization of whole protein. The surface immobilization of short peptides has several advantages: higher stability against conformational change, easy controllability of surface density and orientation, more favorable for ligand-receptor interaction and cell adhesion [220-222]. A blend mixture of PLGA and amine-end-functionalized PLGA has been used to fabricate scaffolds allowing surface immobilization of the peptide. Porous PGLA scaffolds exposing functional end groups toward the aqueous medium have been prepared by a gas foaming/salt leaching method, followed by immobilization of GRGDY onto the surface oriented functional groups via a bi-functional cross-linking agent. It has been demonstrated that seeding and cultivation of bone marrow steam cells within GRGDY modified scaffolds lead to enhanced cell adhesion and differentiation into osteoblast-like cells. The same immobilization method has been applied in electrospinning process to fabricate RGD modified PLGA nanofibers [223].

Peptides can also be attached to the surface of silica-based scaffolds by adsorption (hydrogen bonding) or by covalent bonding to create functionalized nanoporous surfaces. Protein attachment is assisted by the large concentration of $\mathrm{OH}$ groups $(\mathrm{Si}-\mathrm{OH})$ on the surface of sol-gel derived inorganic materials. Certain proteins may not be attached to simple 
$\mathrm{OH}$-groups; however the $\mathrm{OH}$-group-covered glass surface can be functionalized with other organic groups that are tailored for specific protein attachment, such as amines (via aminepropylthriethoxy silane, APTS) [224, 225].

Many peptide sequences involved in cellular interactions by receptor binding have been identified, including RGD, IKVAV and YIGSR [226]. Among these, the RGD sequence, which was first discovered in fibronectin, is probably one of the best known for use in tissue engineering applications. Immobilization of RGD onto 3D matrices improves their cell adhesive properties. RGD, along with other short peptide sequences such as IKVAV, YIGSR, RNAIAEIIKDI from laminin and HAV from $\mathrm{N}$-cadherin, have been enzymatically incorporated into fibrin matrices to enhance neuritis extension $[227,228]$.

Smaller biologically active molecules, for example peptides, containing recognizable by cell receptors amino-acid sequences, can be also employed in the design of surfaces with improved cell attachment [229]. Arg-Gly-Asp (RGD) sequence, that is a peptide fragment presented in many cell adhesive proteins and bonding to the integrin receptors of different type cells, is the most intensively studied [230]. Similar peptide fragments have been immobilized onto the PTFE [231], poly(acrylamide) [232], poly(urethanes) [233, 234], poly(carbonate urethane), PEG [235], and other substrates. RGD-sequences adding induce cell adhesion and assists cell spreading and focal adhesion contacts formation on the otherwise nonadhesive polymers [236-238]. RGD coupling and plasma treatment have a significant influence on the mechanical strength of the yarns as well as cell responses in terms of adherence, proliferation, and differentiation [239]. To improve the endothelial cells adhesion and growth onto the surface of PEG modified poly(urethane), Lin et al. [240] graft the cell adhesive peptide Gly-Arg-Gly-Asp (GRGD) photo chemically. The improvement of cell growth appears to be depending on the density of GRGD grafting.

Be Bartolo et al. [241] modify the surface of poly(etherimid sulphone) membrane to mimic the outside cell environment, that is able to cause specific interactions with hepatocytes and hence the cell adhesion and organisation. They perform plasma deposition of acrylic acid followed by covalent immobilisation of RGD peptide via hydrophilic flexible spacer (linear diamino-PEG). The last one bonds covalently with one of its amino-groups to carboxyl group on the surface and with the other aminogroup forms peptide bond with carboxyl group of the RGD peptide.

Human tissues such as connective, bone, and cardiac are working under mechanical loading and stress in vivo. Lateef et al. have aimed at an increase of the different cell types adhesion to poly(siloxane) surface at in vitro dynamic bending. Therefore they have developed surface modification method, based on a polysiloxane membrane water plasma treatment for 3-aminopropyl-three-ethoxy silane bonding and the aminosilane to be utilized for covalent GRGDSPpeptide sequence immobilization to the amino-groups by maleinimid cross-linker. Cardiac myoblasts demonstrate improved adhesion to such peptide-coupled membranes [242]. RGD immobilized plasma pretreated PLA scaffolds have demonstrated not only improved adhesion of osteoblast cells but also supported growth and differentiation and enhanced mineralization and formation of bone-like tissues [243, 244].

The natural environment for most cells is tissue extra cellular matrix, which is generally a type of hydrogel. Hydrogels are therefore potential materials for tissue engineering. The surface of hydrogels can be modified to tailor them to specific cell types. For example, the attachment of two extra cellular matrix protein sequences (Arg-Cly-Asp and Pro-His-Ser-Arg-Asn) to PEG hydrogel has been shown to increase osteoblasts cell function and also to decrease extracellular matrix production [245]. The immobilization of other biological molecules, like poly- and oligosaccharides or glycolipids also influences not only the cell attachment but also their function [246].

Chemo-selective legation is a more recent approach to chemical modification of biomaterial surfaces that involves a selective covalent coupling of unique and mutually reactive functional groups under mild conditions. Selected pears of groups are used to couple biomimetic peptides and other bioactive molecules to material surfaces via stable bonds without the needs of activating agent or interfering with other functional groups [247]. These reactions are highly chemoselective and behave like molecular "Velcro" [248]. The high efficiency and selectivity of the amino-oxyaldehyde coupling reaction has been successfully demonstrated by attaching a variety of substances to proteins and immobilizing amino-oxy terminated RGD cyclopeptides to substrate surfaces $[249,250]$. The oxime ligatation is compatible with most standard amino acid residues and the oxime bond is known to be reasonably stable both in vitro and in vivo.

Another approach to generate biomimetically-enhanced environment is to recreate the topographical context of native ECM through engineered three-dimensional nanofibrous matrices. The well-established, polymer-based processing method of electro-spinning and thermally induced phase separation, and protein self-assembly are all used to generate nanofibrous metrices [251-253]. Surface functional groups can be introduced in this case also by chemical treatments, such as alkaline hydrolysis, aminolysis, and oxidation/reduction reactions, silanation, chlorination, acylation, and quaternisation reactions.

Mata et al. [254] prepare micro textured PDMS surfaces to study the behavior of human bone connective tissue progenitor cells. Nanostructured poly(hydroxy-methyl siloxane) surfaces have been prepared by plasma treatment or lowenergy ion beam to study the adhesion and proliferation of both, peritrocites and endothelial cells. It is supposed that the biomaterial surface properties can mediate and modulate the cell/surface adhesion via stereo-specific chemical interactions and/or electrostatic repulsion that can explain the different behavior of the peritrocites and the epithelial cells [255].

Polymeric scaffolds could be designed to function more actively in tissue remodeling and regeneration by growth factors incorporation. Heparin modification has been intensively studied for growth factor releasing matrices in tissue 
engineering. Heparin is a highly sulfated glycosoaminoglycan (GAG) constituting the extracellular matrix known for its specific interaction with various angiogenic growth factors [256]. Heparin binding preserve the stability and biological activity of the growth factors. A wide variety of scaffold matrices, including nanofibers, prepared from collagen, fibrin, chitosan, alginate, PLA and PLGA, have been immobilized with heparin to achieve sustained release of growth factors [257-262]. Growth factors can be incorporated into the scaffold matrix either by bulk encapsulation, specific or nonspecific surface adsorption and adding microspheres encapsulating them.

The formation of blood vessels, providing facile transport of oxygen and nutrients is essential for the survival of growing tissue or organ in the tissue engineering [263]. Various angiogenetic growth factors, such as vascular endothelial growth factor (VEGF), acidic or basic fibroblast growth factor (aFGF, bFGF), angiopoietin, and platelet-derived growth factor (PDGF), have been incorporated into 3D matrices. However, serious problems reside in maintaining structural integrity and bioactivity of the protein at the direct encapsulation [264]. Simple physical adsorption of growth factors on the surface of scaffolds could partially solve this problem [265]. Porous poly(lactic acid) (PLA) sponges have been surface coated with bFGF. Engraftment of hepatocytes followed by implantation has resulted in improved blood vessel in-growth with increasing the extent of cell survival. However, the physical adsorption method failed to induce angiogenesis when implanted, due to lack of long-term sustained release effects at the local tissue side. To achieve sustained release of angiogenic growth factors from the scaffold, heparin immobilized scaffolds have been prepared which can interact with heparin-binding angiogenic growth factors, including VEGF and bFGF with specific binding affinity [266-268].

Yoon et al. [269] fabricated macroporous PLGA scaffolds using blending mixture of PLGA and $\mathrm{NH}_{2}$-PEG-PLGA to generate surface amine groups for heparin immobilization. bFGF binding and release studies showed that bFGF sustained release while retaining its bioactivity as determined by proliferation of endothelial cells in vitro. When bFGF loaded heparin modified scaffolds have been implanted in vivo, significantly enhanced neovascularization has been observed. Heparin immobilized microspheres also release out bioactive bFGF in a sustained manner and exhibit pronounced angiogenic effect in an animal model [270, 271].

Porous scaffolds for bone and cartilage regeneration can be further enhanced by altering the surface properties through covalent coupling of cell growth factors. Covalently couplet protein gradients within three-dimensional fibrous scaffolds are crucial for generation of the gradient futures required in the formation of more complex skeletal tissues, such as osteohondral systems [272]. The majority of currently used implant materials in orthopedics lacks osteoconductivity. A number of surface modification techniques (hydrothermal-electrochemical deposition, plasma spraying, ion beam assisted deposition, and biomimetic deposition) have been employed to solve this problem. Furthermore, biomimetic processes have been also employed to render nonbioactive polymer tissue engineering scaffolds osteoconductive [273].

Stimuli (physical-, chemical- or biological)-responsive biomaterials creation is one of the latest directions. For example, the polymer hydrogels may be induced to swell or shrink in response to a variety of environmental stimuli, such as changes in $\mathrm{pH}$ or temperature, or the presence of a specific chemical substrate. When hydrogels swell or shrink, complex patterns may be generated on their surface. The character of gel surface can be modified by selectively depositing another material using a mask, for example, deposition of small areas of N-isopropylacrylamide (NIPA) gels on the surface of an acrylamide gel [274]. Ebara et al. [275] create PDMS micro channel system with stimuli responsive surface grafting poly(N-isopropylacryl amide) (PNIPA) onto the photoinitiator preadsorbed channel walls. The grafting density and the corresponding reversible hydrophilic/hydrophobic properties (water contact angle of about $35^{\circ}$ below the critical solution temperature and of $82^{\circ}$ above it) are controlled by varying the UV irradiation time and the photoinitiator amount. Stoica et al. [276] present new synthetic rout to couple selectively a modified octa-peptide, that is able to gel at low temperature, to the prototypical thermoresponsive poly(N-isopropylacryl amide) to give bioconjugate that exhibits double thermoresponsiveness.

\section{Summary and Future Outlook}

Polymeric biomaterials with controlled protein adsorption and cellular interactions are currently of extremely increasing interest, mainly because of their potential for applications in the regenerative medicine and tissue engineering. Repairing or replacing of damaged tissues or organs requires biocompatible materials that emulate living tissues. A future challenge is to modify biomaterials used for this purpose in a way that they imitate in their composition and/or structure the native physiological conditions for the tissue specific cells. Surface engineering plays an important role in the development of such biomaterials. Enormous research activity is focused now on the delivering of new and improved biomimetic biomaterials.

The level of biological complexity that needs to be recapitulated within a synthetic three-dimensional environment is still uncertain and further understanding of the interactions occurring at cell surface/substrate interface requires. It is likely that biofunctionalization strategies will continue to play a key role because they integrate micronand nanoscale features into designed scaffolds better.

Development of stimuli-responsive polymeric biomaterials is expected to enable feedback-controlled scaffold structures for tissue engineering. Having a built-in adaptation of physical properties, such as elasticity or permeability, for example, similar synthetic polymer architectures will come closer to dynamic nature of the living matter.

The development of new strategies to creation of surface engineered biomaterials with improved biocontact properties (providing a biomimetic microenvironment conductive to cell adhesion, proliferation, differentiation, and host tissue 
integration) requires a more in-depth investigation on the mechanisms of protein adsorption and reorganization, as well as of the bioadhesion and cell/biomaterial and cell/extra cellular matrix interactions, cell signaling and cell growth biology.

\section{References}

[1] N. Minoura, S. Aiba, Y. Fujiwara, N. Koshizaki, and Y. Imai, "The interaction of cultured cells with membranes composed of random and block copolypeptides," Journal of Biomedical Materials Research, vol. 23, no. 2, pp. 267-279, 1989.

[2] R. Large, MRS Bulletin, vol. 31, p. 447, 2004.

[3] B.-S. Kim and D. J. Mooney, "Development of biocompatible synthetic extracellular matrices for tissue engineering," Trends in Biotechnology, vol. 16, no. 5, pp. 224-229, 1998.

[4] R. Langer and J. P. Vacanti, “Tissue engineering," Science, vol. 260, no. 5110, pp. 920-926, 1993.

[5] L. L. Hench and J. M. Polak, "Third-generation biomedical materials," Science, vol. 295, no. 5557, pp. 1014-1017, 2002.

[6] J. Anderson, "A forecast of the future for biomaterials," in Proceedings of the Future of Biomedical Materials (key note), Symposium, Imperial Colleage London, September 2005.

[7] S. E. Sakiyama-Elbert and J. A. Hubbell, "Functional biomaterials: design of novel biomaterials," Annual Review of Materials Science, vol. 31, pp. 183-201, 2001.

[8] L. Bachakova, Physiological Research, vol. 53, pp. 35-45, 2004.

[9] C.-G. Gölander, Preparation and properties of functionalized polymer surfaces, Ph.D. thesis, The Royal Institute of Technology, Stockholm, Sweden, 1986.

[10] M. Malmsten, Ed., Biopolymers at Interfaces, Marcel Dekker, New York, NY, USA, 1998.

[11] S. Pasche, Mechanisms of protein resistance of adsorbed PEGGraft copolymers, D.Sc. thesis, Swiss Federal Institute of Technology, Zurich, Switzerland, 2004.

[12] S. Drotleff, Polymers and protein-conjugates for tissue engineering, Ph.D. thesis, University of Regensburg, Regensburg, Germany, 2006.

[13] V. Hlady, R. A. VanWagenen, and J. D. Andrade, in Surface and Interfacial Aspects of Biomedical Polymers, J. D. Andrade, Ed., vol. 2, p. 81, Plenum Press, New York, NY, USA, 1985.

[14] M. Jager, C. Zilkens, K. Zanger, and R. Krauspe, "Significance of nano- and microtopography for cell-suraface interactions in orthopedic implants," Journal of Biomedicine and Biotechnology, vol. 2007, Article ID 69036, 2007.

[15] G. Altankov, Cell/biomaterial surfaces interaction, D.Sc. thesis, Institute of Biophysics, BAS, Sofia, Bulgaria, 2003.

[16] F. Grinnell and M. K. Feld, "Adsorption characteristics of plasma fibronectin in relationship to biological activity," Journal of Biomedical Materials Research, vol. 15, no. 3, pp. 363-381, 1981.

[17] J. D. Andrade and V. Hlady, "Protein adsorption and materials biocompatibility. A tutorial review and suggested hypothesis," Progress in Surface Science, vol. 79, pp. 1-63, 1986.

[18] V. Prasad, "Strategies for de novo engineering of tissues," in Proceedings of the NATO ARW Nano-Engineered Systems for Regenerative Medicine, Varna, Bulgaria, September 2007.

[19] J. Panell, "Material surface effects on biological interactions," in Proceedings of the NATO ARW Nano-Engineered Systems for Regenerative Medicine, Varna, Bulgaria, September 2007.

[20] J. Champion, "UROs, tacos, worms and surfboards: what they teach about material-cell interactions," in Proceedings of the NATO ARW Nano-Engineered Systems for Regenerative Medicine, Varna, Bulgaria, September 2007.

[21] W. Senaratne, P. Sengupta, V. Jakubek, D. Holowka, C. K. Ober, and B. Baird, "Functionalized surface arrays for spatial targeting of immune cell signaling," Journal of the American Chemical Society, vol. 128, no. 17, pp. 5594-5595, 2006.

[22] W. Senaratne, L. Andruzzi, and C. K. Ober, "Self-assembled monolayers and polymer brushes in biotechnology: current applications and future perspectives," Biomacromolecules, vol. 6, no. 5, pp. 2427-2448, 2005.

[23] S. Sano, K. Kato, and Y. Ikada, "Introduction of functional groups onto the surface of polyethylene for protein immobilization," Biomaterials, vol. 14, no. 11, pp. 817-822, 1993.

[24] A. Hoffman, Annals of the New York Academy of Sciences, pp. 97-101, 1988.

[25] P. K. Chu, J. Y. Chen, L. P. Wang, and N. Huang, "Plasmasurface modification of biomaterials," Materials Science and Engineering, vol. 36, no. 5-6, pp. 143-206, 2002.

[26] C. M. Chan, Polymer Surface Modification and Characterization, chapters 5-7, Hanser, Brookfield, Wis, USA, 1993.

[27] F. Abbasi, H. Mirzadeh, and A.-A. Katbab, "Modification of polysiloxane polymers for biomedical applications: a review," Polymer International, vol. 50, no. 12, pp. 1279-1287, 2001.

[28] U. Vohrer, "Interfacial engineering of functional textiles for biomedical applications," in Plasma Technologies for Textiles, R. Shishoo, Ed., p. 202, CRC Press; Boca Raton, Fla, USA, Woodhead, Cambridge, UK, 2007.

[29] C.-M. Chan, T.-M. Ko, and H. Hiraoka, "Polymer surface modification by plasmas and photons," Surface Science Reports, vol. 24, no. 1-2, pp. 1-54, 1996.

[30] K. R. Rau, Surface modification of biomaterials by pulsed laser ablasion deposition and plasma/gamma polymerization, Ph.D. thesis, University of Florida, Gainesville, Fla, USA, 2001.

[31] R. Shishoo, Ed., Plasma Technologies for Textiles, CRC Press; Boca Raton, Fla, USA, Woodhead, Cambridge, UK, 2007.

[32] A. Denizli, E. Piskin, V. Dixit, M. Arthur, and G. Gitnick, "Collagen and fibronectin immobilization of PHEMA microcarriers for hepatocyte attachment," International Journal of Artificial Organs, vol. 18, no. 2, pp. 90-95, 1995.

[33] S. Jaumotte-Thelen, I. Dozot-Dupont, J. MarchandBrynaert, and Y.-J. Schneider, "Covalent grafting of fibronectin and asialofetuin at surface of poly(ethylene terephthalate) track-etched membranes improves adhesion but not differentiation of rat hepatocytes," Journal of Biomedical Materials Research, vol. 32, no. 4, pp. 569-582, 1996.

[34] R. Chen and J. A. Hunt, "Biomimetic materials processing for tissue-engineering processes," Journal of Materials Chemistry, vol. 17, no. 38, pp. 3974-3979, 2007.

[35] S. P. Massia and J. A. Hubbell, "Human endothelial cell interactions with surface-coupled adhesion peptides on a nonadhesive glass substrate and two polymeric biomaterials," Journal of Biomedical Materials Research, vol. 25, no. 2, pp. 223-242, 1991.

[36] Y. Ykada, M. Suzuki, and Y. Tamada, "Polymer surfaces possessing minimal interaction with blood components," in Polymers as Biomaterials, Plenum Press, New York, NY, USA, 1984.

[37] S. E. Sakiyama-Elbert and J. A. Hubbell, "Functional biomaterials: design of novel biomaterials," Annual Review of Materials Science, vol. 31, pp. 183-201, 2001.

[38] B. D. Ratner, Biocompatibility of Clinical Implant Materials, vol. 2 of D. W. Williams, Eds., CRC Press, Boca Raton, Fla, USA, 1981. 
[39] A. S. Hoffman, T. A. Horbett, and B. D. Ratner, "Interactions of blood and blood components at hydrogel interfaces," Annals of the New York Academy of Sciences, vol. 283, pp. 372 382, 1977.

[40] W. Kim and J. Feijen, "Surface modification of polymers for improved blood compatibility," CRC Critical Reviews in Biocompatibility, vol. 1, p. 229, 1985.

[41] K. Ishihara, Biocompatible Polymers, CRC Press, London, UK, 1994.

[42] B. D. Ratner and A. S. Hoffman, "Non-fouling surfaces," in Biomaterials Science, B. D. Ratner, A. S. Hoffman, F. J. Schoen, and J. E. Lemons, Eds., pp. 197-201, Elsevier, San Diego, Calif, USA, 2nd edition, 2004.

[43] J. M. Harries, Ed., Poly(Ethylene Glycol) Chemistry. Biomedical and Biotechnical Applications, Plenum Press, New York, NY, USA, 1992.

[44] C.-G. Gölander, S. Jönsson, T. Vladkova, P. Stenius, and J. C. Eriksson, "Preparation and protein adsorption properties of photopolymerized hydrophilic films containing Nvinylpyrrolidone (NVP), acrylic acid (AA) or ethyleneoxide (EO) units as studied by ESCA," Colloids \& Surfaces, vol. 21, pp. 149-165, 1986.

[45] C.-G. Gölander, E.-S. Jönsson, T. Vladkova, et al., "Protein adsorption on some photo-polymerized hydrophilic films," in Proceedings of the 8th International Symposium on Plasma Chemistry (IUPAC'87), vol. 8.27, Sofia, Bulgaria, July 1987.

[46] M. Malmsten and J. M. Van Alstine, "Adsorption of poly(ethylene glycol) amphiphiles to form coatings which inhibit protein adsorption," Journal of Colloid and Interface Science, vol. 177, no. 2, pp. 502-512, 1996.

[47] C.-G. Gölander, E.-S. Jönsson, and T. G. Vladkova, "EP022966 (B1); WO8602087 (A1); US4840851 (A); SU1729284 (A3); SE8404866 (L); SE444950 (B); NO861998 (A); JP62500307 (T); DK248986 (A); AU4965185 (A)".

[48] T. Vladkova, "Modification of polymer surfaces for medical application," in Proceedings of the 13th Science Conference "Modification of Polymers", Kudowa Zdroj, Poland, September 1995.

[49] T. G. Vladkova, C.-G. Gölander, S. C. Christoskova, and E.S. Jönsson, "Mechanically stable hydrophilic films based on oxialkylated macromers polymerizable by UV irradiation," Polymers for Advanced Technologies, vol. 8, no. 6, pp. 347-350, 1997.

[50] T. Vladkova, Some Possibilities to Polymer Surface Modification, UCTM Ed. Centre, Sofia, Bulgaria, 2001.

[51] T. Vladkova, E.-S. Jönsson, and C.-G. Gölander, "Surface modification of natural rubber latex films by peg hydrogel coating," Journal of University of Chemical Technology and Metallurgy, vol. 38, p. 131, 2003.

[52] T. Vladkova, "Surface modification of silicone rubber with poly(ethylene glycol) hydrogel coatings," Journal of Applied Polymer Science, vol. 92, no. 3, pp. 1486-1492, 2004.

[53] R. Bischoff and G. Bischoff, in Proceedings of the 11th Conference of the European Society of Biomechanics, Touluse, France, July 1998.

[54] B. P. Lee, K. Huang, F. N. Nunalee, K. Shull, and P. B. Messersmith, "Synthesis of 3,4-dihydroxyphenylalanine (DOPA) containing monomers and their co-polymerization with PEG-diacrylate to form hydrogels," Journal of Biomaterials Science, Polymer Edition, vol. 15, no. 4, pp. 449-464, 2004.

[55] I. K. Kwon and T. Matsuda, "Photo-iniferter-based thermoresponsive block copolymers composed of poly(ethylene glycol) and poly( $\mathrm{N}$-isopropylacrylamide) and chondrocyte immobilization," Biomaterials, vol. 27, no. 7, pp. 986-995, 2006.

[56] M. S. Hahn, L. J. Taite, J. J. Moon, M. C. Rowland, K. A. Ruffino, and J. L. West, "Photolithographic patterning of polyethylene glycol hydrogels," Biomaterials, vol. 27, no. 12, pp. 2519-2524, 2006.

[57] S. Kizilel, E. Sawardecker, F. Teymour, and V. H. PérezLuna, "Sequential formation of covalently bonded hydrogel multilayers through surface initiated photopolymerization," Biomaterials, vol. 27, no. 8, pp. 1209-1215, 2006.

[58] Y. Ito, H. Hasuda, M. Sakuragi, and S. Tsuzuki, "Surface modification of plastic, glass and titanium by photoimmobilization of polyethylene glycol for antibiofouling," Acta Biomaterialia, vol. 3, no. 6, pp. 1024-1032, 2007.

[59] E. Kiss, C.-G. Gölander, and J. C. Eriksson, "Surface grafting of polyethyleneoxide optimized by means of ESCA," Progress in Colloid \& Polymer Science, vol. 74, no. 1, pp. 113-119, 1987.

[60] C. L. Feng, Z. Zhang, R. Förch, W. Knoll, G. J. Vancso, and H. Schönherr, "Reactive thin polymer films as platforms for the immobilization of biomolecules," Biomacromolecules, vol. 6, no. 6, pp. 3243-3251, 2005.

[61] R. Schlapak, P. Pammer, D. Armitage, et al., "Glass surfaces grafted with high-density poly(ethylene glycol) as substrates for DNA oligonucleotide microarrays," Langmuir, vol. 22, no. 1, pp. 277-285, 2006.

[62] S. Patel, R. G. Thakar, J. Wong, S. D. McLeod, and S. Li, "Control of cell adhesion on poly(methyl methacrylate)," Biomaterials, vol. 27, no. 14, pp. 2890-2897, 2006.

[63] Y. Li, C. G. Worley, R. W. Linton, J. M. DeSimone, and E. T. Samulski, "Grafting of poly(ethylene oxide) to crosslinked polystyrene and polypropylene substrates with well-controlled chain length and functionalities," Division of Polymer Chemistry-American Chemical Society, vol. 37, no. 2, pp. 737-738, 1996.

[64] K.C. Popat, G. Mor, C. A. Grimes, and T. A. Desai, "Surface modification of nanoporous alumina surfaces with poly(ethylene glycol)," Langmuir, vol. 20, no. 19, pp. 80358041, 2004.

[65] J. Piehler, A. Brecht, R. Valiokas, B. Liedberg, and G. Gauglitz, "A high-density poly(ethylene glycol) polymer brush for immobilization on glass-type surfaces," Biosensors and Bioelectronics, vol. 15, no. 9-10, pp. 473-481, 2000.

[66] Z.-K. Xu, F.-Q. Nie, C. Qu, L.-S. Wan, J. Wu, and K. Yao, "Tethering poly(ethylene glycol)s to improve the surface biocompatibility of poly(acrylonitrile-co-maleic acid) asymmetric membranes," Biomaterials, vol. 26, no. 6, pp. 589-598, 2005.

[67] J. Groll, T. Ameringer, J. P. Spatz, and M. Moeller, "Ultrathin coatings from isocyanate-terminated star PEG prepolymers: layer formation and characterization," Langmuir, vol. 21, no. 5, pp. 1991-1999, 2005.

[68] I. Choi, S. K. Kang, J. Lee, Y. Kim, and J. Yi, "In situ observation of biomolecules patterned on a PEG-modified Si surface by scanning probe lithography," Biomaterials, vol. 27, no. 26, pp. 4655-4660, 2006.

[69] H. Xu, J. L. Kaar, A. J. Russell, and W. R. Wagner, "Characterizing the modification of surface proteins with poly(ethylene glycol) to interrupt platelet adhesion," Biomaterials, vol. 27, no. 16, pp. 3125-3135, 2006.

[70] Y. G. Ko, Y. H. Kim, K. D. Park, et al., "Immobilization of poly(ethylene glycol) or its sulfonate onto polymer surfaces by ozone oxidation," Biomaterials, vol. 22, no. 15, pp. 21152123, 2001. 
[71] R. P. Sebra, K. S. Masters, C. Y. Cheung, C. N. Bowman, and K. S. Anseth, "Detection of antigens in biologically complex fluids with photografted whole antibodies," Analytical Chemistry, vol. 78, no. 9, pp. 3144-3151, 2006.

[72] M. Beyer, T. Felgenhauer, F. R. Bischoff, F. Breitling, and V. Stadler, "A novel glass slide-based peptide array support with high functionality resisting non-specific protein adsorption," Biomaterials, vol. 27, no. 18, pp. 3505-3514, 2006.

[73] D. Xiao, H. Zhang, and M. Wirth, "Chemical modification of the surface of poly(dimethylsiloxane) by atom-transfer radical polymerization of acrylamide," Langmuir, vol. 18, no. 25, pp. 9971-9976, 2002.

[74] T. Goda, T. Konno, M. Takai, T. Moro, and K. Ishihara, "Biomimetic phosphorylcholine polymer grafting from polydimethylsiloxane surface using photo-induced polymerization," Biomaterials, vol. 27, no. 30, pp. 5151-5160, 2006.

[75] T. Vladkova, N. Krasteva, A. Kostadinova, and G. Altankov, "Preparation of PEG-coated surfaces and a study for their interaction with living cells," Journal of Biomaterials Science, Polymer Edition, vol. 10, no. 6, pp. 609-620, 1999.

[76] S. P. Massia, J. Stark, and D. S. Letbetter, "Surfaceimmobilized dextran limits cell adhesion and spreading," Biomaterials, vol. 21, no. 22, pp. 2253-2261, 2000.

[77] S. K. Thanawala and M. K. Chaudhury, "Surface modification of silicone elastomer using perfluorinated ether," Langmuir, vol. 16, no. 3, pp. 1256-1260, 2000.

[78] S. Yang, J. Wang, K. Ogino, S. Valiyaveettil, and C. K. Ober, "Low-surface-energy fluoromethacrylate block copolymers with patternable elements," Chemistry of Materials, vol. 12, no. 1, pp. 33-40, 2000.

[79] L. Andruzzi, W. Senaratne, A. Hexemer, et al., "Oligo(ethylene glycol) containing polymer brushes as bioselective surfaces," Langmuir, vol. 21, no. 6, pp. 24952504, 2005.

[80] S. S. Hwang, C. K. Ober, S. Perutz, D. R. Iyengar, L. A. Schneggenburger, and E. J. Kramer, "Block copolymers with low surface energy segments: siloxane- and perfluoroalkanemodified blocks," Polymer, vol. 36, no. 6, pp. 1321-1325, 1995.

[81] S. Krishnan, R. Ayothi, A. Hexemer, et al., "Anti-biofouling properties of comblike block copolymers with amphiphilic side chains," Langmuir, vol. 22, no. 11, pp. 5075-5086, 2006.

[82] S. Krishnan, N. Wang, C. Ober, C. Finlay, J. Callow, and M. Callow, Biomacromolecules, vol. 117, pp. 2775-2783, 2009.

[83] T. Vladkova, "Modification of polymer surfaces for medical application," in Proceedings of the 13th International Science Conference "Modification of Polymers", Kudowa Zdroj, Poland, September 1995.

[84] Y. Kicheva, T. Vladkova, V. Kostov, and C.-G. Gölander, "Preparation of surface modified PVC drain tubing and in vivo study of their biocompatibility," Journal of the University of Chemical Technology and Metallurgy, vol. 37, pp. 77-84, 2002.

[85] Y. Kicheva, V. Kostov, M. Mateev, and T. Vladkova, "In vitro and in vivo evaluation of biocompatibility of PVC materials with modified surfaces," in Proceedings of the 6th Colloquium on Biomaterials, Aahen, Germany, September 2002.

[86] P. Sioshansi and E. J. Tobin, "Surface treatment of biomaterials by ion beam processes," Surface and Coatings Technology, vol. 83, no. 1-3, pp. 175-182, 1996.

[87] M. Szicher, P. Sioshansi, and E. Frish, Biomaterials for the 1990s:Polyurethanes, Silicones, and Ion Beam Modification Techniques, Part 2, Spire, Bedford, Mass, USA, 1990.
[88] M. Inoue, Y. Suzuki, and T. Takagi, "Review of Ion Engineering Center and related projects in Ion Engineering Research Institute," Nuclear Instruments and Methods in Physics Research B, vol. 121, no. 1-4, pp. 1-6, 1997.

[89] I. F. Husein, C. Chan, and P. K. Chu, "Chemical structure modification of silicone surfaces by plasma immersion ion implantation," Journal of Materials Science Letters, vol. 19, no. 21, pp. 1883-1885, 2000.

[90] I. F. Husein, C. Chan, S. Qin, and P. K. Chu, "The effect of high-dose nitrogen plasma immersion ion implantation on silicone surfaces," Journal of Physics D, vol. 33, no. 22, pp. 2869-2874, 2000.

[91] C. Satriano, S. Carnazza, S. Guglielmino, and G. Marletta, "Differential cultured fibroblast behavior on plasma and ionbeam-modified polysiloxane surfaces," Langmuir, vol. 18, no. 24, pp. 9469-9475, 2002.

[92] B. Bhushan, D. Hansford, and K. K. Lee, "Surface modification of silicon and polydimethylsiloxane surfaces with vaporphase-deposited ultrathin fluorosilane films for biomedical nanodevices," Journal of Vacuum Science and Technology A, vol. 24, no. 4, pp. 1197-1202, 2006.

[93] W. J. Sear, P. P. Capek, and F. J. Clubb, in Proceedings of the 40th Annual Conference on ADAIO, New York, NY, USA, April 1998.

[94] L. Hakelius and L. Ohlsen, "A clinical comparison of the tendency to capsular contracture between smooth and textured gel-filled silicone mammary implants," Plastic and Reconstructive Surgery, vol. 90, no. 2, pp. 247-254, 1992.

[95] K. Ishihara, "Blood compatible polymers," in Biomedical Applications of Polymeric Materials, T. Tsuruta, T. Hyashi, K. Kataoka, K. Ishihara, and Y. Kimura, Eds., CRC Press, Boca Raton, Fla, USA, 1993.

[96] D.-C. Sin, H.-L. Kei, and X. Miao, "Surface coatings for ventricular assist devices," Expert Review of Medical Devices, vol. 6, no. 1, pp. 51-60, 2009.

[97] P. Claesson and C.-G. Gölander, Colloids and Surfaces, vol. 20, p. 186, 1995.

[98] D. L. Coleman, D. E. Gregonis, and J. D. Andrade, "Bloodmaterials interactions: the minimum interfacial free energy and the optimum polar/apolar ratio hypotheses," Journal of Biomedical Materials Research, vol. 16, no. 4, pp. 381-398, 1982.

[99] M. D. Lelah, J. A. Pierce, L. K. Lambrecht, and S. L. Cooper, "Polyether-urethane ionomers: surface property/ex vivo blood compatibility relationships," Journal of Colloid and Interface Science, vol. 104, no. 2, pp. 422-439, 1985.

[100] S. Nagaoka, Y. Mory, and S. Nishiumi, "Interaction between blood components and hydrogels with polyoxyethylene chains," Polymer Preprints, vol. 34, no. 1, p. 67, 1983.

[101] H. Tanzawa, "Biomedical polymers: current status and overview," in Biomedical Applications of Polymeric Materials, T. Tsuruta, T. Hayashi, K. Kataoka, K. Ishihara, and Y. Kimura, Eds., p. 12, CRC Press, Boca Raton, Fla, USA, 1993.

[102] S. Hattori, J. D. Andrade, J. B. Hibbs Jr., D. E. Gregonis, and R. N. King, "Fibroblast cell proliferation on charged hydroxyethyl methacrylate copolymers," Journal of Colloid and Interface Science, vol. 104, no. 1, pp. 72-78, 1985.

[103] N. Minoura, S. Aiba, Y. Fujiwara, N. Koshizaki, and Y. Imai, "The interaction of cultured cells with membranes composed of random and block copolypeptides," Journal of Biomedical Materials Research, vol. 23, no. 2, pp. 267-279, 1989.

[104] H. Sato, A. Nakajima, T. Hayashi, G. W. Chen, and Y. Noishiki, "Microheterophase structure, permeability, and 
biocompatibility of A-B-A triblock copolymer membranes composed of poly(gamma-ethyl L-glutamate) as the A component and polybutadiene as the B component," Journal of Biomedical Materials Research, vol. 19, no. 9, pp. 1135$1155,1985$.

[105] T. Okano, T. Aoyagi, K. Kataoka, et al., "Hydrophilichydrophobic microdomain surfaces having an ability to suppress platelet aggregation and their in vitro antithrombogenicity," Journal of Biomedical Materials Research, vol. 20, no. 7, pp. 919-927, 1986.

[106] T. Okano, M. Uruno, N. Sugiyama, et al., "Suppression of platelet activity on microdomain surfaces of 2-hydroxyethyl methacrylate-polyether block copolymers," Journal of Biomedical Materials Research, vol. 20, no. 7, pp. 1035-1047, 1986.

[107] K. D. Park, T. Okano, C. Nojiri, and S. W. Kim, "Heparin immobilization onto segmented polyurethaneurea surfaces—effect of hydrophilic spacers," Journal of Biomedical Materials Research, vol. 22, no. 11, pp. 977-992, 1988.

[108] T. Okada and Y. Ikada, Makromolekulare Chemie, vol. 192, p. 1705, 1991.

[109] S. M. Kirkham and M. E. Dangel, "The keratoprosthesis: improved biocompatability through design and surface modification," Ophthalmic Surgery, vol. 22, no. 8, pp. 455-461, 1991.

[110] T. Okada and Y. Ikada, "Tissue reactions to subcutaneously implanted, surface-modified silicones," Journal of Biomedical Materials Research, vol. 27, no. 12, pp. 1509-1518, 1993.

[111] Y. Kinoshita, T. Kuzuhara, M. Kirigakubo, M. Kobayashi, K. Shimura, and Y. Ikada, "Soft tissue reaction to collagenimmobilized porous polyethylene: subcutaneous implantation in rats for $20 \mathrm{wk}$," Biomaterials, vol. 14, no. 3, pp. 209$215,1993$.

[112] H. Mirzadeh, A. A. Katbab, and R. P. Burford, "CO2pulsed laser induced surface grafting of acrylamide onto ethylene-propylene-rubber (EPR)—I," Radiation Physics and Chemistry, vol. 41, no. 3, pp. 507-519, 1993.

[113] H. Mirzadeh, M. T. Khorasani, A. A. Katbab, et al., "Biocompatibility evaluation of laser-induced AAm and HEMA grafted EPR-part 1: in-vitro study," Clinical Materials, vol. 16, no. 4, pp. 177-187, 1994.

[114] H. Mirzadeh, A. A. Katbab, M. T. Khorasani, R. P. Burford, E. Gorgin, and A. Golestani, "Cell attachment to laser-induced AAm- and HEMA-grafted ethylene-propylene rubber as biomaterial: in vivo study," Biomaterials, vol. 16, no. 8, pp. 641-648, 1995.

[115] M. T. Khorasani, H. Mirzadeh, and P. G. Sammes, "Laser induced surface modification of polydimethylsiloxane as a super-hydrophobic material," Radiation Physics and Chemistry, vol. 47, no. 6, pp. 881-888, 1996.

[116] H. Mirzadeh, M. Khorasani, and P. G. Sammes, "Laser surface modification of polymers. A novel technique for the preparation of blood compatible materials (II): in vitro assay," Iranian Polymer Journal, vol. 7, no. 1, pp. 5-13, 1998.

[117] M. T. Korasani, H. Mirzadeh, and P. G. Sammes, in Surface Modification Technologies, T. Sudarshan, A. Khor, and M. Eandin, Eds., p. 499, Institute of Materials, London, UK, 1996.

[118] M. T. Khorasani, H. Mirzadeh, and P. G. Sammes, "Laser surface modification of polymers to improve biocompatibility: HEMA grafted PDMS, in vitro assay-III," Radiation Physics and Chemistry, vol. 55, no. 5-6, pp. 685-689, 1999.
[119] R. Lasson, Chemical constitution and biological properties of heparinized surface, Ph.D. thesis, Karolinska Institute, Stockholm, Sweden, 1980.

[120] H. J. Steffen, J. Schmidt, and A. Gonzalez-Elipe, "Biocompatible surfaces by immobilization of heparin on diamond-like carbon films deposited on various substrates," Surface and Interface Analysis, vol. 29, no. 6, pp. 386-391, 2000.

[121] Y. Susuki, M. Kasakabe, M. Iwaki, and M. Suzuki, Nuclear Instruments and Methods in Physics Research, vol. B32, p. 120, 1998.

[122] Y. Susuki, C. Swapp, M. Kasakabe, and M. Iwaki, Nuclear Instruments and Methods in Physics Research, vol. B46, p. 354, 1990.

[123] Y. Suzuki, M. Kusakabe, M. Iwaki, H. Akiba, K. Kusakabe, and S. Sato, "In vivo evaluation of antithrombogenicity for ion implanted silicone usineg in -111-tropolone-platelets," Japanese Journal of Artificial Organs, vol. 19, no. 3, pp. 10921095, 1990.

[124] P. R. Udall, in Dialysis Therapy, A. R. Nilsen and R. N. Fine, Eds., Hanley \& Belfus, Philadelphia, Pa, USA, 2nd edition, 1993.

[125] J. Anderson, "The future of biomedical materials (key note)," in Proceedings of a Forecast of the Future for Biomaterials, Imperial Colleage, September 2005.

[126] A. R. Boccaccini and J. J. Blaker, "Bioactive composite materials for tissue engineering scaffolds," Expert Review of Medical Devices, vol. 2, no. 3, pp. 303-317, 2005.

[127] E. Eisenbarth, "Biomaterials for tissue engineering," Advanced Engineering Materials, vol. 9, no. 12, pp. 10511060, 2007.

[128] M. M. Stevens, R. P. Marini, D. Schaefer, J. Aronson, R. Langer, and V. P. Shastri, "In vivo engineering of organs: the bone bioreactor," Proceedings of the National Academy of Sciences of the United States of America, vol. 102, no. 32, pp. 11450-11455, 2005.

[129] C. Weinand, I. Pomerantseva, C. M. Neville, et al., "Hydrogel- $\beta$-TCP scaffolds and stem cells for tissue engineering bone," Bone, vol. 38, no. 4, pp. 555-563, 2006.

[130] J. Jones, Materials Today, vol. 9, no. 12, p. 35, 2006.

[131] H. J. Chung and T. G. Park, "Surface engineered and drug releasing pre-fabricated scaffolds for tissue engineering," Advanced Drug Delivery Reviews, vol. 59, no. 4-5, pp. 249262, 2007.

[132] G. Altankov, "Development of provisional extracellular matrix on the biomaterial interface: lessons from in vitro cell culture," in Proceedings of the NATO Advanced Research Workshop on Nanoengineered Systems for Regenerative Medicine, Varna, Bulgaria, September 2007.

[133] M. J. Lydon, T. W. Minett, and B. J. Tighe, "Cellular interactions with synthetic polymer surfaces in culture," Biomaterials, vol. 6, no. 6, pp. 396-402, 1985.

[134] K. Smetana Jr., "Cell biology of hydrogels," Biomaterials, vol. 14, no. 14, pp. 1046-1050, 1993.

[135] H.-B. Lin, W. Sun, D. F. Mosher, et al., "Synthesis, surface, and cell-adhesion properties of polyurethanes containing covalently grafted RGD-peptides," Journal of Biomedical Materials Research, vol. 28, no. 3, pp. 329-342, 1994.

[136] R. G. Flemming, C. J. Murphy, G. A. Abrams, S. L. Goodman, and P. F. Nealey, "Effects of synthetic micro- and nanostructured surfaces on cell behavior," Biomaterials, vol. 20, no. 6, pp. 573-588, 1999.

[137] K. Saha, J. F. Pollock, D. V. Schaffer, and K. E. Healy, "Designing synthetic materials to control stem cell phenotype," 
Current Opinion in Chemical Biology, vol. 11, no. 4, pp. 381387, 2007.

[138] L. Moroni, J. A. A. Hendriks, R. Schotel, J. R. de Wijn, and C. A. van Blitterswijk, "Design of biphasic polymeric 3-dimensional fiber deposited scaffolds for cartilage tissue engineering applications," Tissue Engineering, vol. 13, no. 2, pp. 361-371, 2007.

[139] D.-A. Wang, S. Varghese, B. Sharma, et al., "Multifunctional chondroitin sulphate for cartilage tissue-biomaterial integration," Nature Materials, vol. 6, no. 5, pp. 385-392, 2007.

[140] H. Lee, S. M. Dellatore, W. M. Miller, and P. B. Messersmith, "Mussel-inspired surface chemistry for multifunctional coatings," Science, vol. 318, no. 5849, pp. 426-430, 2007.

[141] D. S. W. Benoit, A. R. Durney, and K. S. Anseth, "The effect of heparin-functionalized PEG hydrogels on three-dimensional human mesenchymal stem cell osteogenic differentiation," Biomaterials, vol. 28, no. 1, pp. 66-77, 2007.

[142] M. P. Ludolf and J. A. Hubbel, "Synthetic biomaterials as instructive extracellular microenvironments for morphogenesis in tissue engineering," Nature Biotechnology, vol. 25, pp. 47-55, 2007.

[143] H. J. Chung and T. G. Park, "Surface engineered and drug releasing pre-fabricated scaffolds for tissue engineering," Advanced Drug Delivery Reviews, vol. 59, no. 4-5, pp. 249262, 2007.

[144] G. Altankov, T. Vladkova, N. Krasteva, A. Kostadinova, and I. Keranov, "Preparation of protein repellent PEI/PEG coatings and fibronectin reorganization study on the coated surfaces," Journal of the University of Chemical Technology and Metallurgy, vol. 44, no. 4, pp. 333-340, 2009.

[145] G. Altankov and T. Groth, "Reorganization of substratumbound fibronectin on hydrophilic and hydrophobic materials is related to biocompatibility," Journal of Materials Science, vol. 5, no. 9-10, pp. 732-737, 1994.

[146] G. Altankov and T. Groth, "Fibronectin matrix formation by human fibroblasts on surfaces varying in wettability," Journal of Biomaterials Science, Polymer Edition, vol. 8, no. 4, pp. 299310, 1996.

[147] C. F. Amstein and P. A. Hartman, "Adaptation of plastic surfaces for tissue culture by glow discharge," Journal of Clinical Microbiology, vol. 2, no. 1, pp. 46-54, 1975.

[148] G. N. Hannan and B. R. McAuslan, "Immobilized serotonin: a novel substrate for cell culture," Experimental Cell Research, vol. 171, no. 1, pp. 153-163, 1987.

[149] J. A. Chinn, T. A. Horbett, B. D. Ratner, M. B. Schway, Y. Haque, and S. D. Hauschka, "Enhancement of serum fibronectin adsorption and the clonal plating efficiencies of Swiss mouse 3T3 fibroblast and MM14 mouse myoblast cells on polymer substrates modified by radiofrequency plasma deposition," Journal of Colloid and Interface Science, vol. 127, no. 1, pp. 67-87, 1989.

[150] S.-D. Lee, G.-H. Hsiue, and C.-Y. Kao, "Preparation and characterization of a homobifunctional silicone rubber membrane grafted with acrylic acid via plasma-induced graft copolymerization," Journal of Polymer Science A, vol. 34, no. 1, pp. 141-148, 1996.

[151] C. Satriano, E. Conte, and G. Marletta, "Surface chemical structure and cell adhesion onto ion beam modified polysiloxane," Langmuir, vol. 17, no. 7, pp. 2243-2250, 2001.

[152] C. Satriano, S. Carnazza, S. Guglielmino, and G. Marletta, "Differential cultured fibroblast behavior on plasma and ionbeam-modified polysiloxane surfaces," Langmuir, vol. 18, no. 24, pp. 9469-9475, 2002.
[153] T. Vladkova, I. Keranov, and G. Altankov, "Preparation and properties of PDMS surfaces grafted with acrylic acid via plasma pretment or ion-beam induced graft copolymerization," in Proceedings of the 4th International Conference on Chemical Societies of the South-Eastern European Countries (ICOSECS '04), Belgrad, Serbia, July 2004, A-P 26.

[154] T. Vladkova, I. Keranov, P. Dineff, and G. Altankov, "Ionbeam assisted surface modification of PDMS," in Proceedings of the 18th Congres of Chemists and Technologiest of Macedonia, Ohrid, Macedonia, September 2004, PPM-16.

[155] R. Hippler, S. Pfau, M. Schmidt, and K. Schönbach, Eds., Low Temperature Plasma Physics. Fundamental Aspects and Applications, Willey-VCH, Berlin, Germany, 2000.

[156] T. G. Vladkova, I. L. Keranov, P. D. Dineff, et al., "Plasma based Ar+ beam assisted poly(dimethylsiloxane) surface modification," Nuclear Instruments and Methods in Physics Research B, vol. 236, no. 1-4, pp. 552-562, 2005.

[157] I. Keranov, T. G. Vladkova, M. Minchev, A. Kostadinova, G. Altankov, and P. Dineff, "Topography characterization and initial cellular interaction of plasma-based ar1 beam-treated PDMS surfaces," Journal of Applied Polymer Science, vol. 111, no. 5, pp. 2637-2646, 2009.

[158] J. M. Oliveira, I. B. Leonor, and R. L. Reis, "Preparation of bioactive coatings on the surface of bioinert polymers through an innovative auto-catalytic electroless route," Key Engineering Materials, vol. 284-286, pp. 203-206, 2005.

[159] T. Kawai, C. Ohtsuki, M. Kamitakahara, et al., "A comparative study of apatite deposition on polyamide films containing different functional groups under a biomimetic condition," Journal of the Ceramic Society of Japan, vol. 113, no. 1321, pp. 588-592, 2005.

[160] M. Morra, "Biomolecular modification of implant surfaces," Expert Review of Medical Devices, vol. 4, no. 3, pp. 361-372, 2007.

[161] J. L. West, "Biofunctional polymers," in Encyclopedia of Biomaterials and Biomedical Engineering, pp. 89-95, 2007.

[162] A. Denizli, E. Piskin, V. Dixit, M. Arthur, and G. Gitnick, "Collagen and fibronectin immobilization of PHEMA microcarriers for hepatocyte attachment," International Journal of Artificial Organs, vol. 18, no. 2, pp. 90-95, 1995.

[163] S. Jaumotte-Thelen, I. Dozot-Dupont, J. MarchandBrynaert, and Y.-J. Schneider, "Covalent grafting of fibronectin and asialofetuin at surface of poly(ethylene terephthalate) track-etched membranes improves adhesion but not differentiation of rat hepatocytes," Journal of Biomedical Materials Research, vol. 32, no. 4, pp. 569-582, 1996.

[164] R. Chen and J. A. Hunt, "Biomimetic materials processing for tissue-engineering processes," Journal of Materials Chemistry, vol. 17, no. 38, pp. 3974-3979, 2007.

[165] B. B. Hole, J. A. Schwarz, J. L. Gilbert, and B. L. Atkinson, "A study of biologically active peptide sequences (P-15) on the surface of an ABM scaffold (PepGen P-15) using AFM and FTIR," Journal of Biomedical Materials Research A, vol. 74, no. 4, pp. 712-721, 2005.

[166] C. T. Laurencin and L. S. Nain, Eds., Nanotechnology and Tissue Engineering: The Scaffold, CRC Press, Boca Raton, Fla, USA, 2009.

[167] C. R. Nuttelman, D. J. Mortisen, S. M. Henry, and K. S. Anseth, "Attachment of fibronectin to poly(vinyl alcohol) hydrogels promotes NIH3T3 cell adhesion, proliferation, and migration," Journal of Biomedical Materials Research, vol. 57, no. 2, pp. 217-223, 2001. 
[168] R. S. Braty, J. Crean, D. Lappin, and C. Godson, Journal of Biomedical Materials Research, vol. 56, pp. 78-82, 2001.

[169] M. P. Lutolf and J. A. Hubbell, "Synthetic biomaterials as instructive extracellular microenvironments for morphogenesis in tissue engineering," Nature Biotechnology, vol. 23, no. 1, pp. 47-55, 2005.

[170] U. Hersel, C. Dahmen, and H. Kessler, "RGD modified polymers: biomaterials for stimulated cell adhesion and beyond," Biomaterials, vol. 24, no. 24, pp. 4385-4415, 2003.

[171] A. Karkhaneh, H. Mirzadeh, and A. R. Ghaffariyeh, "Twostep plasma surface modification of PDMS with mixture of HEMA and AAC: collagen immobilization and in vitro assays," in Proceedings of the 5th IASTED International Conference on Biomedical Engineering, pp. 433-438, Innsbruck, Austria, February 2007.

[172] V. B. Ivanov, J. Behnisch, A. Hollander, F. Mehdorn, and H. Zimmermann, "Determination of functional groups on polymer surfaces using fluorescence labelling," Surface and Interface Analysis, vol. 24, no. 4, pp. 257-262, 1996.

[173] J. Davies, C. S. Nunnerley, A. C. Brisley, et al., "Argon plasma treatment of polystyrene microtiter wells. Chemical and physical characterisation by contact angle, ToF-SIMS, XPS and STM," Colloids and Surfaces A, vol. 174, no. 3, pp. 287-295, 2000.

[174] F. Poncin-Epaillard and G. Legeay, "Surface engineering of biomaterials with plasma techniques," Journal of Biomaterials Science, Polymer Edition, vol. 14, no. 10, pp. 1005-1028, 2003.

[175] U. König, M. Nitschke, M. Pilz, F. Simon, C. Arnhold, and C. Werner, "Stability and ageing of plasma treated poly(tetrafluoroethylene) surfaces," Colloids and Surfaces B, vol. 25, no. 4, pp. 313-324, 2002.

[176] J. Johns, Materials Today, vol. 11, no. 5, p. 29, 2008.

[177] D. B. Haddow, D. A. Steele, R. D. Short, R. A. Dawson, and S. MacNeil, "Plasma-polymerized surfaces for culture of human keratinocytes and transfer of cells to an in vitro wound-bed model," Journal of Biomedical Materials Research A, vol. 64, no. 1, pp. 80-87, 2003.

[178] B. Li, J. Chen, and J. H.-C. Wang, "RGD peptide-conjugated poly(dimethylsiloxane) promotes adhesion, proliferation, and collagen secretion of human fibroblasts," Journal of Biomedical Materials Research A, vol. 79, no. 4, pp. 989-998, 2006.

[179] G. Sui, J. Wang, C.-C. Lee, et al., "Solution-phase surface modification in intact poly(dimethylsiloxane) microfluidic channels," Analytical Chemistry, vol. 78, no. 15, pp. 55435551, 2006.

[180] Ch. Baquey, F. Palumbo, M. C. Porte-Durrieu, G. Legeay, A. Tressaud, and R. D'Agostino, "Plasma treatment of expanded PTFE offers a way to a biofunctionalization of its surface," Nuclear Instruments and Methods in Physics Research B, vol. 151, no. 1-4, pp. 255-262, 1999.

[181] S. Sano and S. Wong, Chemistry of Protein Conjugation and Cross-Linking, CRC Press, Boca Raton, Fla, USA, 1991.

[182] N. Shangguan, S. Katukojvala, R. Greenberg, and L. J. Williams, "The reaction of thio acids with azides: a new mechanism and new synthetic applications," Journal of the American Chemical Society, vol. 125, no. 26, pp. 7754-7755, 2003.

[183] S. Drotleff, Polymers and protein-conjugates for tissue engineering, Ph.D. thesis, University of Regensburg, Regensburg, Germany, 2006.

[184] T. Hermanson, Bioconjugate Techniques, Academic Press, San Diego, Calif, USA, 1996.
[185] Y. W. Tong and M. S. Shoichet, "Peptide surface modification of poly(tetrafluoroethylene-co-hexafluoropropylene) enhances its interaction with central nervous system neurons," Journal of Biomedical Materials Research, vol. 42, no. 1, pp. 85-95, 1998.

[186] S. P. Massia and J. A. Hubbell, "Human endothelial cell interactions with surface-coupled adhesion peptides on a nonadhesive glass substrate and two polymeric biomaterials," Journal of Biomedical Materials Research, vol. 25, no. 2, pp. 223-242, 1991.

[187] S. P. Massia and J. A. Hubbell, "Covalently attached GRGD on polymer surfaces promotes biospecific adhesion of mammalian cells," Annals of the New York Academy of Sciences, vol. 589, pp. 261-270, 1990.

[188] K. Nilsson and K. Mosbach, "Immobilization of enzymes and affinity ligands to various hydroxyl group carrying supports using highly reactive sulfonyl chlorides," Biochemical and Biophysical Research Communications, vol. 102, no. 1, pp. 449-457, 1981.

[189] K. Nilsson and K. Mosbach, "Tresyl chloride-activated supports for enzyme immobilization," Methods in Enzymology, vol. 135, pp. 65-78, 1987.

[190] K. Nilsson and K. Mosbach, "Immobilization of ligands with organic sulfonyl chlorides," Methods in Enzymology, vol. 104, pp. 56-69, 1984.

[191] R. Benters, C. M. Niemeyer, and D. Whorle, "Dendrimeractivated solid supports for nucleic acid and protein microarrays," ChemBioChem, vol. 2, no. 9, pp. 686-694, 2001.

[192] M. Yang, R. Y. C. Kong, N. Kazmi, and A. K. C. Leung, "Covalent immobilization of oligonucleotides on modified glass/silicon surfaces for solid-phase DNA hybridization and amplification," Chemistry Letters, no. 3, pp. 257-258, 1998.

[193] S. P. Pack, N. K. Kamisetty, M. Nonogawa, et al., "Direct immobilization of DNA oligomers onto the aminefunctionalized glass surface for DNA microarray fabrication through the activation-free reaction of oxanine," Nucleic Acids Research, vol. 35, no. 17, 2007.

[194] A. Dekker, et al., "Improved adhesion and proliferation of human endothelial cells on PE pre-coated with monoclonal antibodies directed against cell membrane antigens and extracellular matrix proteins," in Adhesion and Proliferation of Human Endothelial Cells on Polymeric Surfaces, Optimization Studies, pp. 61-85, 1990.

[195] R. K. O’Reilly, M. J. Joralemon, C. J. Hawker, and K. L. Wooley, "Facile syntheses of surface-functionalized micelles and shell cross-linked nanoparticles," Journal of Polymer Science A, vol. 44, no. 17, pp. 5203-5217, 2006.

[196] K. K. Perkin, J. L. Turner, K. L. Wooley, and S. Mann, "Fabrication of hybrid nanocapsules by calcium phosphate mineralization of shell cross-linked polymer micelles and nanocages," Nano Letters, vol. 5, no. 7, pp. 1457-1461, 2005.

[197] M. L. Becker, L. A. O. Bailey, and K. L. Wooley, "Peptidederivatized shell-cross-linked nanoparticles. 2. Biocompatibility evaluation," Bioconjugate Chemistry, vol. 15, no. 4, pp. 710-717, 2004

[198] M. L. Becker, J. Liu, and K. L. Wooley, "Peptide-polymer bioconjugates: hybrid block copolymers generated via living radical polymerizations from resin-supported peptides," Chemical Communications, vol. 9, no. 2, pp. 180-181, 2003.

[199] J. Riesle, A. P. Hollander, R. Langer, L. E. Freed, and G. Vunjak-Novakovic, "Collagen in tissue-engineered cartilage: types, structure, and crosslinks," Journal of Cellular Biochemistry, vol. 71, no. 3, pp. 313-327, 1998. 
[200] J. Yang, Y. Wan, J. Yang, J. Bei, and S. Wang, "Plasma-treated, collagen-anchored polylactone: its cell affinity evaluation under shear or shear-free conditions," Journal of Biomedical Materials Research A, vol. 67, no. 4, pp. 1139-1147, 2003.

[201] Z. Ma, C. Gao, Y. Gong, and J. Shen, "Cartilage tissue engineering PLLA scaffold with surface immobilized collagen and basic fibroblast growth factor," Biomaterials, vol. 26, no. 11, pp. 1253-1259, 2005.

[202] S. Ber, G. Torun Köse, and V. Hasirci, "Bone tissue engineering on patterned collagen films: an in vitro study," Biomaterials, vol. 26, no. 14, pp. 1977-1986, 2005.

[203] D. L. Wilson, R. Martin, S. Hong, M. Cronin-Golomb, C. A. Mirkin, and D. L. Kaplan, "Surface organization and nanopatterning of collagen by dip-pen nanolithography," Proceedings of the National Academy of Sciences of the United States of America, vol. 98, no. 24, pp. 13660-13664, 2001.

[204] I. Keranov, T. Vladkova, M. Minchev, A. Kostadinova, and G. Altankov, "Preparation, characterization, and cellular interactions of collagen-immobilized PDMS surfaces," Journal of Applied Polymer Science, vol. 110, no. 1, pp. 321-330, 2008.

[205] X. Liu, Y. Won, and P. X. Ma, "Surface modification of interconnected porous scaffolds," Journal of Biomedical Materials Research A, vol. 74, no. 1, pp. 84-91, 2005.

[206] T. Serizawa and M. Akashi, "A novel approach for fabricating ultrathin polymer films by the repetition of the adsorption/drying processes," Journal of Polymer Science A, vol. 37, no. 13, pp. 1903-1906, 1999.

[207] Z. Ma, C. Gao, Y. Gong, and J. Shen, "Cartilage tissue engineering PLLA scaffold with surface immobilized collagen and basic fibroblast growth factor," Biomaterials, vol. 26, no. 11, pp. 1253-1259, 2005.

[208] M.-C. Chen, H.-F. Liang, Y.-L. Chiu, Y. Chang, H.-J. Wei, and H.-W. Sung, "A novel drug-eluting stent spray-coated with multi-layers of collagen and sirolimus," Journal of Controlled Release, vol. 108, no. 1, pp. 178-189, 2005.

[209] X. Wang, H. J. Kim, P. Xu, A. Matsumoto, and D. L. Kaplan, "Biomaterial coatings by stepwise deposition of silk fibroin," Langmuir, vol. 21, no. 24, pp. 11335-11341, 2005.

[210] K. Cai, K. Yao, S. Lin, et al., "Poly(D,L-lactic acid) surfaces modified by silk fibroin: effects on the culture of osteoblast in vitro," Biomaterials, vol. 23, no. 4, pp. 1153-1160, 2002.

[211] A. Chiarini, P. Petrini, S. Bozzini, I. Dal Pra, and U. Armato, "Silk fibroin/poly(carbonate)-urethane as a substrate for cell growth: in vitro interactions with human cells," Biomaterials, vol. 24, no. 5, pp. 789-799, 2003.

[212] I. Dal Pra, P. Petrini, A. Charini, S. Bozzini, S. Farè, and U. Armato, "Silk fibroin-coated three-dimensional polyurethane scaffolds for tissue engineering: interactions with normal human fibroblasts," Tissue Engineering, vol. 9, no. 6, pp. 1113-1121, 2003.

[213] P. Petrini, C. Parolari, and M. C. Tanzi, "Silk fibroinpolyurethane scaffolds for tissue engineering," Journal of Materials Science, vol. 12, no. 10-12, pp. 849-853, 2001.

[214] G. H. Altman, R. L. Horan, H. H. Lu, et al., "Silk matrix for tissue engineered anterior cruciate ligaments," Biomaterials, vol. 23, no. 20, pp. 4131-4141, 2002.

[215] G. H. Altman, H. H. Lu, R. L. Horan, et al., "Advanced bioreactor with controlled application of multi-dimensional strain for tissue engineering," Journal of Biomechanical Engineering, vol. 124, no. 6, pp. 742-749, 2002.

[216] J. S. Mao, H. F. Liu, Y. J. Yin, and K. D. Yao, “The properties of chitosan-gelatin membranes and scaffolds modified with hyaluronic acid by different methods," Biomaterials, vol. 24, no. 9, pp. 1621-1629, 2003.
[217] H. S. Yoo, E. A. Lee, J. J. Yoon, and T. G. Park, "Hyaluronic acid modified biodegradable scaffolds for cartilage tissue engineering," Biomaterials, vol. 26, no. 14, pp. 1925-1933, 2005.

[218] S. R. Hong, Y. M. Lee, and T. Akaike, "Evaluation of a galactose-carrying gelatin sponge for hepatocytes culture and transplantation," Journal of Biomedical Materials Research A, vol. 67, no. 3, pp. 733-741, 2003.

[219] T. G. Park, "Perfusion culture of hepatocytes within galactose-derivatized biodegradable poly(lactide-coglycolide) scaffolds prepared by gas foaming of effervescent salts," Journal of Biomedical Materials Research, vol. 59, no. 1, pp. 127-135, 2002.

[220] M. P. Lutolf and J. A. Hubbell, "Synthetic biomaterials as instructive extracellular microenvironments for morphogenesis in tissue engineering," Nature Biotechnology, vol. 23, no. 1, pp. 47-55, 2005.

[221] U. Hersel, C. Dahmen, and H. Kessler, "RGD modified polymers: biomaterials for stimulated cell adhesion and beyond," Biomaterials, vol. 24, no. 24, pp. 4385-4415, 2003.

[222] E. Ruoslahti, "RGD and other recognition sequences for integrins," Annual Review of Cell and Developmental Biology, vol. 12, pp. 697-715, 1996.

[223] T. G. Kim and T. G. Park, "Biomimicking extracellular matrix: cell adhesive RGD peptide modified electrospun poly(D,L-lactic-co-glycolic acid) nanofiber mesh," Tissue Engineering, vol. 12, no. 2, pp. 221-233, 2006.

[224] H. S. Mansur, Z. P. Lobato, R. L. Oréfice, W. L. Vasconcelos, C. Oliveira, and L. J. Machado, "Surface functionalization of porous glass networks: effects on bovine serum albumin and porcine insulin immobilization," Biomacromolecules, vol. 1, no. 4, pp. 789-797, 2000.

[225] R. F. S. Lenza, J. R. Jones, W. L. Vasconcelos, and L. L. Hench, "In vitro release kinetics of proteins from bioactive foams," Journal of Biomedical Materials Research A, vol. 67, no. 1, pp. 121-129, 2003.

[226] E. Ruoslahti, "RGD and other recognition sequences for integrins," Annual Review of Cell and Developmental Biology, vol. 12, pp. 697-715, 1996.

[227] J. L. Myles, B. T. Burgess, and R. B. Dickinson, "Modification of the adhesive properties of collagen by covalent grafting with RGD peptides," Journal of Biomaterials Science, Polymer Edition, vol. 11, no. 1, pp. 69-86, 2000.

[228] J. C. Schense, J. Bloch, P. Aebischer, and J. A. Hubbell, "Enzymatic incorporation of bioactive peptides into fibrin matrices enhances neurite extension," Nature Biotechnology, vol. 18, no. 4, pp. 415-419, 2000.

[229] S. P. Massia and J. A. Hubbell, "Human endothelial cell interactions with surface-coupled adhesion peptides on a nonadhesive glass substrate and two polymeric biomaterials," Journal of Biomedical Materials Research, vol. 25, no. 2, pp. 223-242, 1991.

[230] M. J. Humphries, "The molecular basis and specificity of integrin-ligand interactions," Journal of Cell Science, vol. 97, no. 4, pp. 585-592, 1990.

[231] S. P. Massia and J. A. Hubbell, Journal of Biomedical Materials Research, vol. 25, pp. 249-252, 1991.

[232] B. K. Brandley and R. L. Schnaar, "Covalent attachment of an Arg-Gly-Asp sequence peptide to derivatizable polyacrylamide surfaces: support of fibroblast adhesion and longterm growth," Analytical Biochemistry, vol. 172, no. 1, pp. 270-278, 1988.

[233] H.-B. Lin, W. Sun, D. F. Mosher, et al., "Synthesis, surface, and cell-adhesion properties of polyurethanes containing 
covalently grafted RGD-peptides," Journal of Biomedical Materials Research, vol. 28, no. 3, pp. 329-342, 1994.

[234] H.-B. Lin, Z. C. Zhao, C. Garcia-Echeverria, D. H. Rich, and S. L. Cooper, "Synthesis of a novel polyurethane co-polymer containing covalently attached RGD peptide," Journal of Biomaterials Science, Polymer Edition, vol. 3, no. 3, pp. 217227, 1992.

[235] P. D. Drumheller, D. L. Elbert, and J. A. Hubbell, "Multifunctional poly(ethylene glycol) semi-interpenetrating polymer networks as highly selective adhesive substrates for bioadhesive peptide grafting," Biotechnology and Bioengineering, vol. 43, no. 8, pp. 772-780, 1994.

[236] H.-B. Lin, W. Sun, D. F. Mosher, et al., "Synthesis, surface, and cell-adhesion properties of polyurethanes containing covalently grafted RGD-peptides," Journal of Biomedical Materials Research, vol. 28, no. 3, pp. 329-342, 1994.

[237] S. P. Massia and J. A. Hubbell, Journal of Biomedical Materials Research, vol. 25, pp. 273-282, 1991.

[238] P. D. Drumheller, D. L. Elbert, and J. A. Hubbell, "Multifunctional poly(ethylene glycol) semi-interpenetrating polymer networks as highly selective adhesive substrates for bioadhesive peptide grafting," Biotechnology and Bioengineering, vol. 43, no. 8, pp. 772-780, 1994.

[239] J. Chen, G. H. Altman, V. Karageorgiou, et al., "Human bone marrow stromal cell and ligament fibroblast responses on RGD-modified silk fibers," Journal of Biomedical Materials Research A, vol. 67, no. 2, pp. 559-570, 2003.

[240] Y.-S. Lin, S.-S. Wang, T.-W. Chung, et al., "Growth of endothelial cells on different concentrations of Gly-Arg-GlyAsp photochemically grafted in polyethylene glycol modified polyurethane," Artificial Organs, vol. 25, no. 8, pp. 617-621, 2001.

[241] L. De Bartolo, S. Morelli, A. Piscioneri, et al., "Novel membranes and surface modification able to activate specific cellular responses," Biomolecular Engineering, vol. 24, no. 1, pp. 23-26, 2007.

[242] S. S. Lateef, S. Boateng, T. J. Hartman, C. A. Crot, B. Russell, and L. Hanley, "GRGDSP peptide-bound silicone membranes withstand mechanical flexing in vitro and display enhanced fibroblast adhesion," Biomaterials, vol. 23, no. 15, pp. 3159-3168, 2002.

[243] Y. Hu, S. R. Winn, I. Krajbich, and J. O. Hollinger, "Porous polymer scaffolds surface-modified with arginine-glycineaspartic acid enhance bone cell attachment and differentiation in vitro," Journal of Biomedical Materials Research A, vol. 64, no. 3, pp. 583-590, 2003.

[244] M.-H. Ho, L.-T. Hou, C.-Y. Tu, et al., "Promotion of cell affinity of porous PLLA scaffolds by immobilization of RGD peptides via plasma treatment," Macromolecular Bioscience, vol. 6, no. 1, pp. 90-98, 2006.

[245] D. S. W. Benoit and K. S. Anseth, "The effect on osteoblast function of colocalized RGD and PHSRN epitopes on PEG surfaces," Biomaterials, vol. 26, no. 25, pp. 5209-5220, 2005.

[246] D. L. Elbert and J. A. Hubbell, "Surface treatments of polymers for biocompatibility," Annual Review of Materials Science, vol. 26, no. 1, pp. 365-394, 1996.

[247] J. P. Tam, Q. Yu, and Z. Miao, "Orthogonal ligation strategies for peptide and protein,” Biopolymers, vol. 51, no. 5, pp. 311332, 1999.

[248] J. A. Camarero, Y. Kwon, and M. A. Coleman, "Chemoselective attachment of biologically active proteins to surfaces by expressed protein ligation and its application for "protein chip" fabrication," Journal of the American Chemical Society, vol. 126, no. 45, pp. 14730-14731, 2004.
[249] G. Thumshirn, U. Hersel, S. L. Goodman, and H. Kessler, "Multimeric cyclic RGD peptides as potential tools for tumor targeting: solid-phase peptide synthesis and chemoselective oxime ligation," Chemistry, vol. 9, no. 12, pp. 2717-2725, 2003.

[250] L. Scheibler, P. Dumy, M. Boncheva, et al., "Functional molecular thin films: topological templates for the chemoselective ligation of antigenic peptides to self-assembled monolayers," Angewandte Chemie: International Edition, vol. 38, no. 5, pp. 696-699, 1999.

[251] S. P. Massia and J. A. Hubbell, "Immobilized amines and basic amino acids as mimetic heparin-binding domains for cell surface proteoglycan-mediated adhesion," Journal of Biological Chemistry, vol. 267, no. 14, pp. 10133-10141, 1992.

[252] W.-J. Li, R. Tuli, X. Huang, P. Laquerriere, and R. S. Tuan, "Multilineage differentiation of human mesenchymal stem cells in a three-dimensional nanofibrous scaffold," Biomaterials, vol. 26, no. 25, pp. 5158-5166, 2005.

[253] W.-J. Li, C. T. Laurencin, E. J. Caterson, R. S. Tuan, and F. K. Ko, "Electrospun nanofibrous structure: a novel scaffold for tissue engineering," Journal of Biomedical Materials Research, vol. 60, no. 4, pp. 613-621, 2002.

[254] A. Mata, C. Boehm, A. J. Fleischman, G. Muschler, and S. Roy, "Analysis of connective tissue progenitor cell behavior on polydimethylsiloxane smooth and channel micro-textures," Biomedical Microdevices, vol. 4, no. 4, pp. 267-275, 2002.

[255] G. Assero, C. Satriano, G. Lupo, C. D. Anfuso, G. Marletta, and M. Alberghina, "Pericyte adhesion and growth onto polyhydroxymethylsiloxane surfaces nanostructured by plasma treatment and ion irradiation," Microvascular Research, vol. 68, no. 3, pp. 209-220, 2004.

[256] R. Raman, G. Venkataraman, S. Ernst, V. Sasisekharan, and R. Sasisekharan, "Structural specificity of heparin binding in the fibroblast growth factor family of proteins," Proceedings of the National Academy of Sciences of the United States of America, vol. 100, no. 5, pp. 2357-2362, 2003.

[257] M. J. B. Wissink, R. Beernink, A. A. Poot, et al., "Improved endothelialization of vascular grafts by local release of growth factor from heparinized collagen matrices," Journal of Controlled Release, vol. 64, no. 1-3, pp. 103-114, 2000.

[258] J. S. Pieper, T. Hafmans, P. B. Van Wachem, et al., "Loading of collagen-heparan sulfate matrices with bFGF promotes angiogenesis and tissue generation in rats," Journal of Biomedical Materials Research, vol. 62, no. 2, pp. 185-194, 2002.

[259] S. E. Sakiyama-Elbert and J. A. Hubbell, "Development of fibrin derivatives for controlled release of heparin-binding growth factors," Journal of Controlled Release, vol. 65, no. 3, pp. 389-402, 2000.

[260] J. Li, J. Pan, L. Zhang, X. Guo, and Y. Yu, "Culture of primary rat hepatocytes within porous chitosan scaffolds," Journal of Biomedical Materials Research A, vol. 67, no. 3, pp. 938-943, 2003.

[261] A. T. Gutsche, H. Lo, J. Zurlo, J. Yager, and K. W. Leong, "Engineering of a sugar-derivatized porous network for hepatocyte culture," Biomaterials, vol. 17, no. 3, pp. 387-393, 1996.

[262] J. J. Yoon, H. J. Chung, H. J. Lee, and T. G. Park, “Heparinimmobilized biodegradable scaffolds for local and sustained release of angiogenic growth factor," Journal of Biomedical Materials Research A, vol. 79, no. 4, pp. 934-942, 2006.

[263] H. J. Chung, H. K. Kim, J. J. Yoon, and T. G. Park, "Heparin immobilized porous PLGA microspheres for angiogenic 
growth factor delivery," Pharmaceutical Research, vol. 23, no. 8, pp. 1835-1841, 2006.

[264] D. D. Hile, M. L. Amirpour, A. Akgerman, and M. V. Pishko, "Active growth factor delivery from poly(D,L-lactideco-glycolide) foams prepared in supercritical $\mathrm{CO}_{2}$," Journal of Controlled Release, vol. 66, no. 2-3, pp. 177-185, 2000.

[265] H. Lee, R. A. Cusick, F. Browne, et al., "Local delivery of basic fibroblast growth factor increases both angiogenesis and engraftment of hepatocytes in tissue-engineered polymer devices," Transplantation, vol. 73, no. 10, pp. 1589-1593, 2002.

[266] R. Padera, G. Venkataraman, D. Berry, R. Godavarti, and R. Sasisekharan, "FGF-2/fibroblast growth factor receptor/heparin-like glycosaminoglycan interactions: a compensation model for FGF-2 signaling," FASEB Journal, vol. 13, no. 13, pp. 1677-1687, 1999.

[267] L. D. Thompson, M. Pantoliano, and B. Springer, "Energetic characterization of the basic fibroblast growth factor-heparin interaction: identification of the heparin binding domain," Biochemistry, vol. 33, no. 13, pp. 3831-3840, 1994.

[268] R. Raman, G. Venkataraman, S. Ernst, V. Sasisekharan, and R. Sasisekharan, "Structural specificity of heparin binding in the fibroblast growth factor family of proteins," Proceedings of the National Academy of Sciences of the United States of America, vol. 100, no. 5, pp. 2357-2362, 2003.

[269] J. J. Yoon, H. J. Chung, H. J. Lee, and T. G. Park, "Heparinimmobilized biodegradable scaffolds for local and sustained release of angiogenic growth factor," Journal of Biomedical Materials Research A, vol. 79, no. 4, pp. 934-942, 2006.

[270] H. K. Kim, H. J. Chung, and T. G. Park, "Biodegradable polymeric microspheres with "open/closed" pores for sustained release of human growth hormone," Journal of Controlled Release, vol. 112, no. 2, pp. 167-174, 2006.

[271] H. Lee, H. J. Chung, and T. G. Park, "Perspectives on: local and sustained delivery of angiogenic growth factors," Journal of Bioactive and Compatible Polymers, vol. 22, no. 1, pp. 89114, 2007.

[272] C. P. Vepari and D. L. Kaplan, "Covalently immobilized enzyme gradients within three-dimensional porous scaffolds," Biotechnology and Bioengineering, vol. 93, no. 6, pp. 1130-1137, 2006.

[273] M. Wang, "Surface modification of biomaterials and tissue engineering scaffolds for enhanced osteoconductivity," in Proceedings of the 3rd Kuala Lumpur International Conference on Biomedical Engineering, vol. 15, pp. 22-27, Kuala Lumpur, Malaysia, December 2006.

[274] Z. Hu, Y. Chen, C. Wang, Y. Zheng, and Y. Li, "Polymer gels with engineered environmentally responsive surface patterns," Nature, vol. 393, no. 6681, pp. 149-152, 1998.

[275] M. Ebara, J. M. Hoffman, A. S. Hoffman, and P. S. Stayton, "Switchable surface traps for injectable bead-based chromatography in PDMS microfluidic channels," Lab on a Chip, vol. 6, no. 7, pp. 843-848, 2006.

[276] F. Stoica, C. Alexander, N. Tirelli, A. F. Miller, and A. Saiani, "Selective synthesis of double temperature-sensitive polymer-peptide conjugates," Chemical Communications, no. 37, pp. 4433-4435, 2008. 

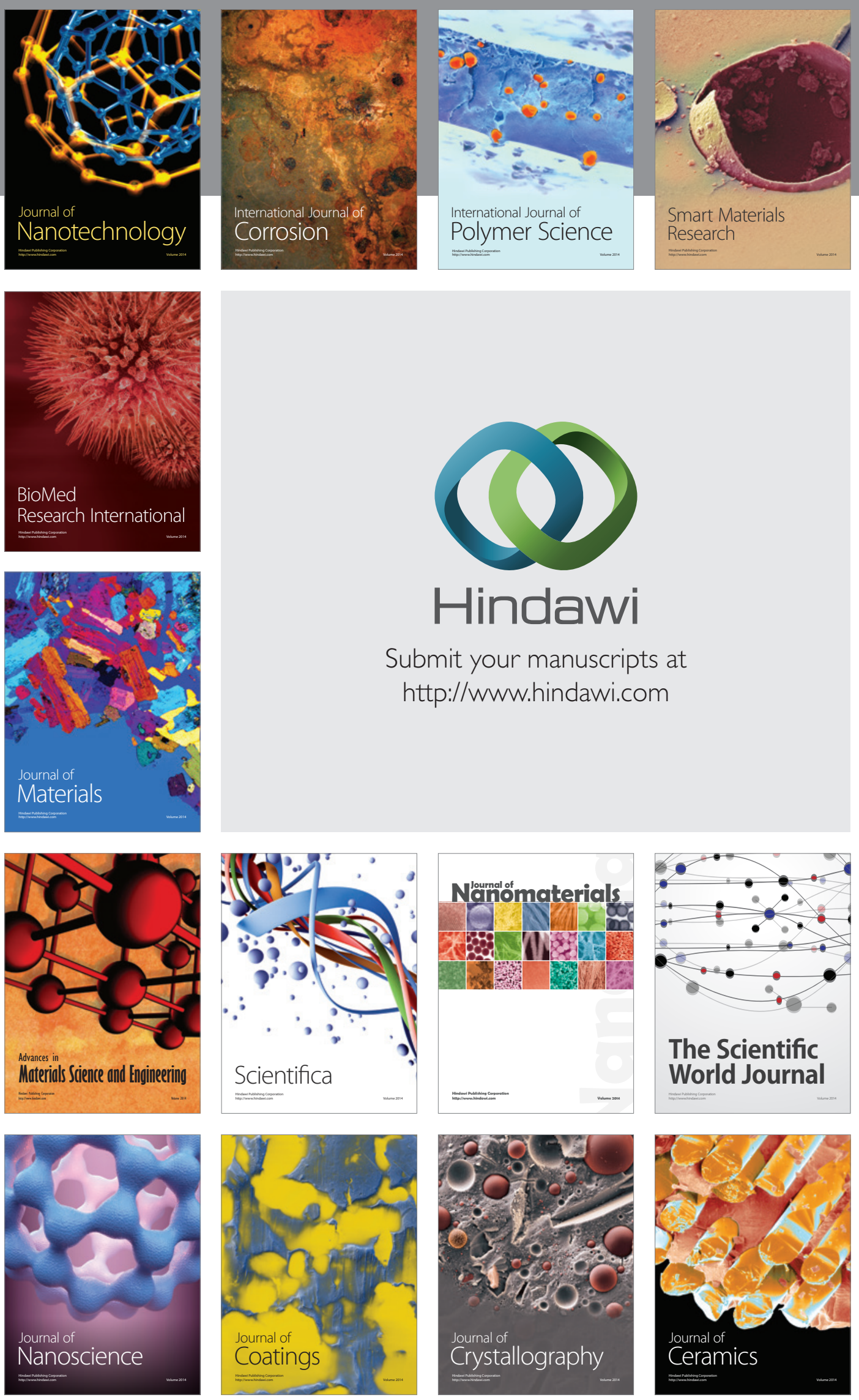

The Scientific World Journal

Submit your manuscripts at

http://www.hindawi.com

\section{World Journal}

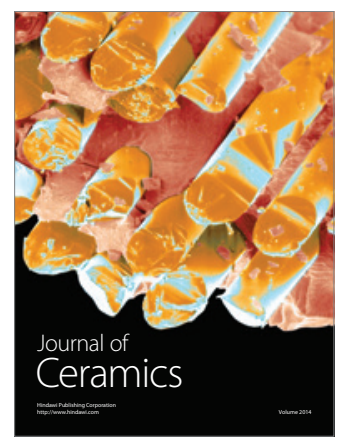

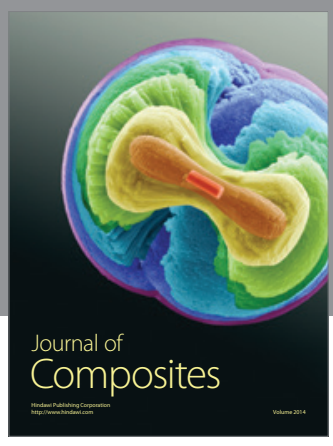
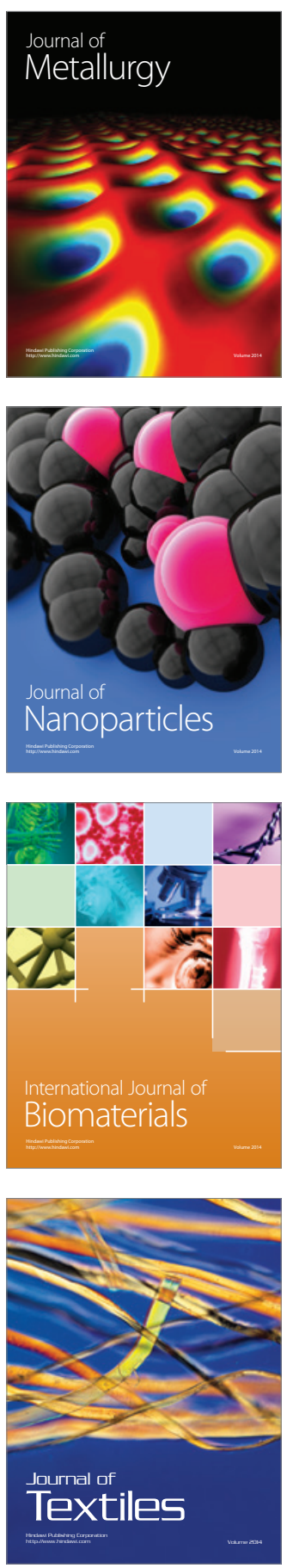